\title{
Undocumented Migrants and the Failures of Universal Individualism
}

\author{
Jaya Ramji-Nogales*
}

\begin{abstract}
In recent years, advocates and scholars have made increasing efforts to situate undocumented migrants within the human rights framework. Few have examined international human rights law closely enough to discover just how limited it is in its protections of the undocumented. This Article takes that failure as a starting point to launch a critique of the universal individualist project that characterizes the current human rights system. It then catalogues in detail the protections available to undocumented migrants in international human rights law, which are far fewer than often assumed. The Article demonstrates through a close analysis of relevant law that the human rights framework contains significant conceptual gaps when it comes to the undocumented. It concludes by suggesting three alternate approaches-substantial reform of the current human rights system state-based political responses, and social movements - to protect undocumented migrants and other vulnerable populations.
\end{abstract}

\footnotetext{
* Associate Professor of Law and Co-Director, Institute for International Law and Public Policy, Temple University, Beasley School of Law. With many thanks to those who provided generous feedback on this project at various stages: Diane Marie Amann, Lina M. Céspedez Báez, Mehrsa Baradaran, Josh Barkan, Jane Baron, Robert Blitt, Harlan Cohen, Margaret deGuzman, Jean Galbraith, Craig Green, Monica Hakimi, David Hoffman, Alexandra Huneeus, Tom Lin, Greg Mandel, Saira Mohamed, Fernanda Nicola, Jamie O'Connell, Jayesh Rathod, Brishen Rogers, Matiangai Sirleaf, David Sloss, Peter Spiro, Shana Tabak, Beth Van Schaack, Stephen Vladeck, and David Zaring. Thanks also to participants in the American Society of International Law's 2013 Human Rights Interest Group Workshop held at Boalt Hall School of Law at the University of California at Berkeley; the American University, Washington College of Law's Faculty Colloquium; the University of Georgia Law's 2013 International Law Colloquium; and the Temple University, Beasley School of Law's Faculty Colloquium. Many thanks to Pamela Fuentes, Katlyn Davis, Denene Wambach, Kenneth Holmboe, and Mike Besmer for outstanding research assistance and to Poliana Irizarry for superb and good-humored library assistance.
} 


\section{TABLE OF CONTENTS}

I. What's Wrong With Human Rights? The

FAILURES OF UNIVERSAL INDIVIDUALISM..................... 705

A. Human Rights Law's Hierarchy of Suffering ... 706

B. Human Rights Law's Disguised Political

Dimensions.......................................................... 708

C. Human Rights Law Obscures Global

Inequality

710

D. Human Rights Law Crowds Out Alternative

Worldviews ....................................................... $\quad 712$

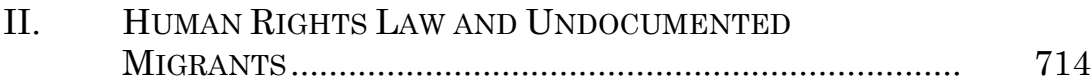

A. Being Undocumented......................................... 714

B. Human Rights from the Perspective of

Undocumented Migrants.................................. $\quad 720$

C. The Contested Content of Human Rights Law.. $\quad 722$

1. Territorial Security .................................. 725

2. Procedural Due Process in Deportation

Proceedings ............................................. $\quad 727$

3. Nondiscrimination Based on

Immigration Status .................................. 730

4. Family Unity ........................................... 733

III. CONSTRUCTING VULNERABILITY: SOVEREIGNTY,

GLOBALIZATION, AND HUMAN RIGHTS ......................... 739

A. History of Human Rights: Sovereignty

B. Globalization and Human Rights:

Manufacturing the Undocumented

Migrant........................................................... $\quad 744$

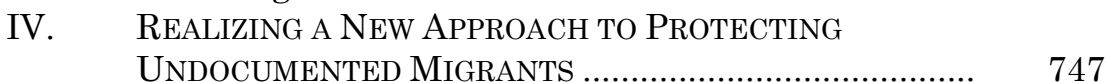

A. Ameliorating the Existing Human Rights

Structure: More Universal, Less

Individualist....

748

B. Long Live Sovereignty?: A State-Based

Approach

750

C. Social Movements: Aggregating Interests

Beyond the State.

758

V. BEyond Human Rights: Engaging WITH

SYSTEMIC INJUSTICE 
In recent years, advocates and scholars have made increasing efforts to situate undocumented migrants within the human rights framework. ${ }^{1}$ Amnesty International's "Immigrants' Rights are Human Rights Campaign" declares that "[a]ll immigrants, irrespective of their legal status, have human rights." 2 The American Civil Liberties Union claims that "[n]umerous international human rights documents firmly establish the principle that no human being can be outside the protection of the law or 'illegal'... [and] that discrimination and abuse based upon immigration status is a violation of human rights." 3 Human Rights Watch goes so far as to suggest that "a human rights framework strongly supports a program of earned legalization for undocumented immigrants in the US." Even Eric Holder, the U.S. Attorney-General, stated recently that "creating a pathway to earned citizenship for the 11 million unauthorized immigrants in this country ... is a matter of ... human rights." 5 In a similar vein, legal scholars have noted that "irregular migrant workers are entitled to the full range of human rights" 6 and

1. Stefanie Grant, Migrants' Human Rights: From the Margins to the Mainstream, MigRATION INFORMATION SOURCE (Mar. 1, 2005), http://www.migrationinformation.org/feature/display.cfm?id=291 [http://perma.cc/ F64K-A4XY] (archived Feb. 15, 2014).

2. Amnesty International, Defending and Advancing Immigrant's Human Rights, AMNESTY INTERNATIONAL: IMMIGRANTS' RIGHTS ARE HUMAN RIGHTS CAMPAIGN, http://www.amnestyusa.org/our-work/campaigns/immigrants-rights-are-human-rights [http://perma.cc/Z2LH-JDGD] (archived Mar. 2, 2014).

3. Immigrants'Rights, AM. CIVIL LIBERTIES UnION, http://www.aclu.org/humanrights/immigrants-rights [http://perma.cc/63XR-LGQ7] (archived Feb. 12, 2014).

4. Why Immigrant Stories Matter: The Human Rights Case for a Path to US Legal Status, HuM. RTS. WATCH, http://www.hrw.org/features/why-immigrant-storiesmatter [http://perma.cc/4EV4-PVBQ] (archived Feb. 16, 2014); see also HEARTLAND ALLIANCE NAT'L IMMIGRANT JUSTICE CENTER, http://www.immigrantjustice.org/ immigrationreform\#.UdLtYdjKodU [http://perma.cc/UFB4-M72M] (archived Feb. 16, 2014) (advocating for immigration reform that coheres with human rights standards); Justin Mazzola, Immigration Reform Must Not Fall Short of Human Rights, AMNESTY INTERNATIONAL: HUMAN RIGHTS NOW BLOG (June 28, 2013, 1:01 PM), http://blog.amnestyusa.org/us/immigration-reform-must-not-fall-short-of-human-rights/ [http://perma.cc/4NK9-ETUZ] (archived Feb. 15, 2014) (advocating immigration reform that meets human rights standards); Speak Out for Immigration Reform that Promotes Human Rights, Justice, and Dignity!, GEORGIA WAND (June 21, 2013), http://gawand.org/2013/06/21/speak-out-for-immigration-reform-that-promotes-humanrights-justice-and-dignity/ [http://perma.cc/N6QG-C6QX] (archived Feb. 16, 2014) (urging support of immigration reform to promote human rights); Immigrant Rights are Human Rights, REFORM IMMIGRATION FOR TEXAS ALLIANCE, http://reformimmigration fortexas.org/1/immigrant-rights-are-human-rights/ [http://perma.cc/VU8A-QR4L] (archived Feb. 16, 2014) (averring that immigrants' rights are human rights).

5. Noah Rothman, Eric Holder: Citizenship for Illegal Immigrants Is a 'Matter of Civil and Human Rights', MEDIAITE (Apr. 26, 2013, 2:53 PM), http://www.mediaite.com/ tv/eric-holder-citizenship-for-illegal-immigrants-is-a-matter-of-civil-and-human-rights/ [http://perma.cc/4R29-YECF] (archived Feb. 16, 2014).

6. Ryszard Cholewinski, The Rights of Migrant Workers, in InTERNATIONAL Migration Law: Developing Paradigms AND Key Challenges 255, 264 (Ryszard Cholewinski, Richard Perruchoud \& Euan MacDonald eds., 2007). 
that "[m]ost human rights are guaranteed irrespective of an individual's immigration status; they are a function of a person's status as a human being, not as a citizen of a particular state."

The assumption underlying these pronouncements is that international human rights law affords undocumented migrants substantial protection against the mistreatment, exploitation, and abuse they face in their host countries. They even suggest that the undocumented are recipients of specific rights under international human rights law, such as the right to nondiscrimination based on immigration status and the right to regularize their status. In reality, the human rights framework's protections of the undocumented are far less robust than these statements suggest. That is the problem this Article takes up in greater detail.

It is understandable, given human rights law's claims to universalism and individualism, that those seeking to assist migrants would turn to the human rights framework as a source of protection. The international treaties that comprise the current human rights regime were drafted as a response to the mass atrocities perpetrated during the Second World War. ${ }^{8}$ The international community set up this new legal structure to ensure that states would no longer be able to arbitrarily deny rights to people within their territory or control; instead, rights would attach to each individual by virtue of their humanity. The protections available within the human rights canon

7. T. Alexander Aleinikoff, International Legal Norms and Migration: A Report, in Migration And InTERnational Legal Norms 1, 8 (T. Alexander Aleinikoff $\&$ Vincent Chetail eds., 2003). These claims are generally tempered by recognition of the limits to protections available to undocumented migrants under international human rights law. However, legal scholars largely point to the expansion of human rights protection as the solution to these limits, rather than questioning the project of universal individualism as this Article does. See, e.g., Cholewinski, supra at 263-65; Aleinikoff, supra at 2; see also DAVID WeIssBRoDT, THE HUMAN Rights OF NoNCitizens 182-204 (2008) (describing limits of human rights protection for undocumented migrants).

8. As explained by Christian Tomuschat:

After the horrors of World War II, a broad consensus emerged at the worldwide level demanding that the individual human being be placed under the protection of the international community. As particularly the atrocities committed against specific ethnic groups had shown, national governments could gravely fail in their duty to ensure the life and the liberty of their citizens. Some had even become murderous institutions. However, never again should a holocaust occur. Accordingly, since the lesson learned was that protective mechanisms at the domestic level alone did not provide sufficiently stable safeguards, it became almost self-evident to entrust the planned new world organization with assuming the role of guarantor of human rights on a universal scale.

See, e.g., Christian Tomuschat, Introductory Note: International Covenant on Civil and Political Rights, United NATIONs Audiovisual LibRARY OF InTERNATIONAL LAW (Dec. 16, 1966), http://legal.un.org/avl/ha/iccpr/iccpr.html [http://perma.cc/Y6HB-VW48] (archived Feb. 16, 2014). 
were to be universally applicable and reflective of shared universal human values.

These were noble and ambitious claims. But has human rights law lived up to its promises? This Article takes universal individualism on its own terms, measuring its success by the standards of universal content and coverage and individual applicability that this approach to human rights sets forth. In other words, this Article uses the case study of undocumented migrants to determine whether the story that universal individualism tells about itself is accurate. On paper, many human rights protections apply to all humans, whether or not they have lawful immigration status. But it is extremely difficult for migrants to exercise these substantive rights when they can be discriminated against based on their immigration status and deported at any time. These vulnerabilities must first be addressed so that undocumented migrants have the ability to claim other rights. ${ }^{9}$ International human rights law offers undocumented migrants insufficient protection against deportation and discrimination, safeguarding instead sovereign interests in territorial control. Rather than protecting the vulnerable against sovereign abuses, universal individualism has entrenched existing power imbalances. The perspective of undocumented migrants is not adequately reflected in the ostensibly shared universal values manifested in current human rights law.

These failures of protection raise larger questions about the universal individualist approach to human rights. This Article begins with a systematic critique of the failures of universal individualism. The current human rights project presents a false universalism that erases certain forms of suffering from popular discourse. These claims to transcendent universalism imply that human rights law is apolitical thereby disguising the political choices that determine its content. Human rights law's narrow focus on the individual obscures larger questions of structural inequality. The individualist approach presents an atomistic conception of society that overlooks the importance of social ties and group-based identities.

After setting out this critical framework, the Article describes who undocumented migrants are and which rights and values they might prioritize if the universalist approach were to include their voices. It next explores the contested content of four such rights: the right to territorial security, the right to procedural due process in deportation proceedings, the right to nondiscrimination based on immigration status, and the right to family unity. The latter right is the most widely available to undocumented migrants, though still limited; the first is unavailable in any forum. The absence of a right to territorial security is particularly problematic because it renders

9. See, e.g., HANNAH ARENDT, The ORIgins of TOTALitarianism 292-96 (1958) (discussing the rights denied to stateless persons). 
undocumented migrants vulnerable and unable to protect themselves against exploitation and abuse.

This Article next briefly discusses why the universal individualist approach to human rights has failed to protect undocumented migrants. It suggests that, contrary to common perception, human rights law may actually reinforce sovereign interests and exacerbate the harmful effects of globalization on vulnerable populations. This Part begins with a critical history of the relationship between human rights and sovereignty, highlighting the evolution of the universal individualist approach over time. It then focuses on the interaction of globalization and human rights, illustrating the role of global economic inequity in creating migration flows and explaining how the universal individualist approach furthers this distributive inequality.

In the world of social justice, universal individualism in the form of international human rights law has become the hegemon. Efforts to protect vulnerable populations begin and end with human rights. Particularly in legal scholarship, strategies to ameliorate the situation of vulnerable groups outside the scope of human rights law focus on how that law might be extended to cover these groups. Given the failures of universal individualism, this Article suggests instead other approaches outside of or alongside international human rights law that might more effectively protect undocumented migrants and other vulnerable populations.

Using the criticisms of universal individualism as a roadmap, this Article provides three alternative approaches to protecting vulnerable populations. It first lays out ways in which the existing human rights structure could be reformed to minimize the shortcomings of the universal individualist approach. It next presents a state-based approach to social change, discussing methods through which migrant-sending states can work individually and in coalition with other states to protect their nationals in migrant-receiving states. Finally, the Article suggests a social movements approach to protecting undocumented migrants, in the form of counterhegemonic transnational networks. It ends with a call to examine critically the universal individualist approach to human rights and to envision alternative ways to protect vulnerable populations by engaging more broadly with global structural injustice.

The aim of this Article is not to work within existing systems to create social change but to push readers to reimagine what is possible when it comes to protecting undocumented migrants. Even the imaginations of those who seek to protect undocumented migrants are currently impoverished by the strictures of the international human rights framework that governs most social change efforts. This Article is thus an attempt to liberate the discourse around undocumented migrants from the dominant human rights hegemon. 


\section{What's Wrong With Human Rights? The FaILURES OF UNIVERSAL INDIVIDUALISM}

Before engaging in a sustained critique of the universal individualist approach to rights, or human rights as we know them, it is important to note the incredible successes of human rights law in alleviating vulnerability for many people. It is also important to acknowledge the complexity of human rights as a concept. The term human rights can refer to a set of legal standards or institutions, particular social or political movements, or a group of moral values and social norms. ${ }^{10}$ This Article defines human rights according to the legal standards laid out in international treaty law and soft law but is also concerned with the ways in which those standards shape social norms and constrain the imagination of social movements.

With this complexity in mind, the terms universal and individualist need to be defined. From a human rights law perspective, universal can have at least two meanings. It could mean that these rights are universally applicable, belonging "to every human being in every human society." 11 It could also mean that the content of these rights is universally agreed upon, or "deemed essential for individual well-being, dignity, and fulfillment, and... [reflecting] a common sense of justice, fairness, and decency."12 This Part examines both interpretations. Individualist means that these rights attach to people as individuals, creating claims by individuals against states. We have, then, a set of rights the scope of which ostensibly reflects the shared values of all human beings and that applies to every human being as an individual.

Drawing on literature critical of rights-based approaches domestically and internationally, this Part explores four central problems with the current approach to human rights, which this Article labels universal individualism. Human rights law's overstated claims to universality of content erase the suffering of those outside its scope. Similarly, human rights law's implied claim to transcendence, or separateness from the realm of the political, limits effective responses to its shortcomings. Human rights law's prioritization of individual rights obscures economic and political inequality on a global scale. Finally, an individualist approach impedes alternative group-based approaches that might be more

10. Philip Alston, Does the Past Matter? On the Origins of Human Rights, 126 HARV. L. REV. 2043, 2078 (2013) (reviewing JENNY S. MARTINEZ, ThE SLAVE TRADE AND THE ORIGINS OF INTERNATIONAL HUMAN RIGHTS LAW (2012)).

11. Louis Henkin, The Age of Rights 2 (1990); see also Universal Declaration of Human Rights, pmbl., G.A. Res. 217 (III) A, U.N. Doc. A/RES/317(III) (Dec. 10, 1948) [hereinafter UDHR] (referring to the rights of "all members of the human family").

12. HENKIN, supra note 11, at 2; see UDHR, supra note 11, at pmbl. (noting that "the peoples of the United Nations have . . reaffirmed their faith in fundamental human rights"). 
successful in improving the situation of undocumented migrants and others.

\section{A. Human Rights Law's Hierarchy of Suffering}

Human rights law fails in its claims to universality of applicability, as illustrated in further detail through the example of undocumented migrants. This overclaiming prevents groups whose fundamental rights lie outside the scope of international human rights law from obtaining protection, rendering such groups vulnerable to exploitation and abuse. International human rights law has become the hegemon of antivulnerability discourse, such that rights not included in its canon can be dismissed as not worthy of protection. This is particularly troubling given that the limitations on the content of human rights law reflect the priorities of powerful interests that human rights law claims to combat. Moreover, the locating of certain forms of vulnerability outside the scope of human rights dismisses such claims to protection from the discourse altogether.

Several scholars have noted that reliance on a rights-based framework creates a hierarchy of suffering that prioritizes the "supposedly unjust suffering" of certain "innocent" victims at the expense of others who suffer in different ways or are less able to meet increasingly strict and unrealistic standards of morality. ${ }^{13}$ Rights necessarily establish categories and must by definition rank members of some categories above members of other categories. These stigmatized categories are the basis for exclusion of certain groups from protection. In this way, rights accommodate subordination through law. ${ }^{14}$ Rights can be viewed as "trump cards" that allow some subsets of migrants to attain fundamental rights, while others become vulnerable to exploitation and abuse because they cannot squeeze themselves into the appropriate category laid out by the rights framework. ${ }^{15}$

The hierarchies created by these legal categories also influence moral values and social norms. The prioritizing of certain rights in international human rights law erases other rights from the discourse and from popular imagination. In the realm of international

13. See, e.g., Upendra Baxi, Voices of Suffering and the Future of Human Rights, 8 Transnat'L L. \& ConTEMP. Probs. 125, 154-55 (1998); Marie-Bénédicte Dembour \& Marie Martin, The French Calais: Transit Zone or Dead-End?, in ARE Human Rights For MigRANTS?: CRITICAL REFleCtions ON THE STATUS OF IRREGUlaR Migrants in EuRope AND the United States 123, 142-45 (Marie-Bénédicte Dembour \& Tobias Kelly eds., 2011); DAVID KenNedy, The DARK SIDES OF VIRTUE 14-15 (2004).

14. See Colin Dayan, The Story of Cruel \& Unusual 57 (2007) (discussing the human rights implications of the treatment of prisoners is supermax prisons).

15. KennedY, supra note 13, at 17; Martti Koskeniemmi, Human Rights Mainstreaming as a Strategy for Institutional Power, 1 HuMANITY 47, 48 (2010). 
human rights law, individuals fleeing persecution and torture are granted certain rights to nondiscrimination based on immigration status, procedural due process rights in deportation proceedings, and, if they win their claim, the right to territorial security. ${ }^{16}$ Undocumented migrants fleeing poverty and starvation are awarded few, if any, of these rights, in the text of international human rights treaties or otherwise. ${ }^{17}$ They are instead branded "economic migrants" who have entered their host country in violation of the law, and who should therefore be accorded only a limited set of human rights. ${ }^{18}$ Undocumented migrants are thus depicted by human rights law itself as somehow less than human.

The expressive dimension of these hierarchies should not be underestimated. ${ }^{19}$ States understand that they need not expend effort protecting those outside the scope of human rights law and can instead focus their limited resources on the rights of those who fall within the human rights framework. The legal categories also circumscribe the scope of the debate, focusing public discussion around migrants on questions of immigration status rather than inequality and need. The categorical hierarchies created by human rights law impoverish the imagination even of those who seek to uphold migrants' rights.

This critique does not necessarily lead to an outright rejection of human rights as a method of social change. The inherent limitations of a rights framework might be moderated through closer attention to concealed categories and their expressive dimension. In some cases, the power of the law may be so valuable in achieving certain ends that it outweighs the problems of the method. But those seeking to ameliorate vulnerability should approach human rights law in a measured fashion, with awareness of its flaws and hidden consequences.

16. Convention Relating to the Status of Refugees arts. 13-24, 26, 32-34, Apr. 22, 1951, 189 U.N.T.S. 137 (providing rights to equal treatment as nationals in some areas and other noncitizens in other areas and the right not to be returned to persecution and to naturalization); Convention Against Torture and Other Cruel, Inhuman, or Degrading Treatment or Punishment art. 3, June 26, 1987, 1465 U.N.T.S. 85 (providing the right not to be returned to torture); International Covenant on Civil and Political Rights art. 13, Dec. 10, 1984, 999 U.N.T.S. 171 [hereinafter ICCPR] (providing the right to procedural due process in immigration proceedings); see also Jaya Ramji-Nogales, A Global Approach to Secret Evidence: How Human Rights Law Can Reform Our Immigration System, 39 Colum. Hum. RTS. L. REV. 287, 287-95 (2008) (describing the rights accorded under U.S. law to immigrants fleeing persecution, torture, or both).

17. See infra Part II.

18. See infra Part II.

19. See, e.g., Cass R. Sunstein, On the Expressive Function of Law, 144 U. PA. L. REV. 2021, 2024 (1996) (defining "the expressive function of law [as] the function of law in 'making statements' as opposed to controlling behavior directly"). 


\section{B. Human Rights Law's Disguised Political Dimensions}

Human rights law's claims to universality of content rest upon the idea that there is a set of fundamental rights that exist across countries and cultures. This presupposes a cluster of moral values free of political and cultural constraints, an assumption that is not just misguided but dangerous. ${ }^{20}$ Decisions about whose norms should define what rights and in relation to what sort of collectivity are firmly rooted in specific political and cultural contexts. ${ }^{21}$ Claims of universality obscure the ex ante political choices that determine the scope of human rights. ${ }^{22}$ Of even greater concern, the "trump card" nature of rights renders these masked political decisions untouchable, entrenching them in a milieu that is allegedly beyond politics. ${ }^{23}$

Claims of universal agreement on the content of human rights are at odds with the diversity of cultures, moral values, and political arrangements available in the nearly two hundred countries of the world. ${ }^{24}$ The discussion below of the human rights of undocumented migrants demonstrates the contested content of many rights. In just one example, Latin American human rights bodies extend broader rights to undocumented migrants than international human rights bodies that reflect to a greater extent the values of migrant-receiving states. A broad range of rights remains subject to serious debate within and across societies. ${ }^{25}$

20. See Charles R. Beitz, The Idea of Human Rights 201-03 (2009) (explaining that "human rights are in some significant sense Western in content and origin and lack a foundation in the world's other moral cultures"); JACK DONNELLY, Universal Human Rights IN TheORY \& PRACTICE 91 (2d ed. 2003); Jaya RamjiNogales, Designing Bespoke Transitional Justice: A Pluralist Process Approach, 32 MiCH. J. INT'L L. 1, 3 (2010) (critiquing "universalist" approaches to international criminal law derived from Western criminal standards that "are often strikingly different from those of the societies that transitional justice seeks to impact").

21. Frederick Cooper, Afterword: Social Rights and Human Rights in the Time of Decolonization, 3 HUMAN. 473, 475 (2012).

22. See BALAKRISHNAN RAJAGOPAL, INTERNATIONAL LAW FROM BELOW: DEvelopment, SOCIAL MOVEMENTS AND THIRD WorLD RESISTANCE 206 (2003) (noting that "human rights discourse presents itself as neutral, apolitical, legal, and nonideological").

23. KENNEDY, supra note 13 , at 17 ; see Koskeniemmi, supra note 15 , at 48 ("[N]atural rights have frankly undemocratic implications, suggesting as they do that human communities are bound by the values that precede them. It depends on political theology.").

24. See Makau Mutua, Human Rights: A Political \& Cultural Critique 64-66 (2002) (presenting the "cultural pluralist" critique, which focuses on the "distinctly Eurocentric formulation of human rights discourse" and rejects the "specific cultural and historical experiences of the West as the standard for all humanity").

25. See Stephen H. Legomsky, Portraits of the Undocumented Immigrant: A Dialogue, 44 GA. L. REV. 65, 138 (2009) ("No one is seriously proposing that undocumented immigrants be tortured, or deprived of food and water, or criminally convicted without a fair trial. For the most part, however, human rights law doesn't 
Even the handful of values that might arguably be claimed as shared across cultures and nations break down upon closer examination. For example, few would argue with the idea of an "inherent right to life" of which "[n]o-one shall be arbitrarily deprived" if we conceptualize that right as prohibiting murder. ${ }^{26}$ But some would find that this right prohibits capital punishment, while others would argue that the death penalty is not arbitrary but a legitimate form of punishment. ${ }^{27}$ Some would view this provision as prohibiting abortion, while others would argue that human rights law supports a woman's right to choose whether to terminate her pregnancy.

Arguments that widespread ratification of international human rights treaties reflects universal consensus on the content of rights miss an important point. These treaties are ratified by states, and states often do not represent the views of their populations in part or in whole. ${ }^{28}$ Indeed, representatives of states in the developing world may come from Western-educated elites whose perspectives on which rights matter differ from and even conflict with the perspectives of the poor and the working class. Cultures and societies are too complex to be distilled into a common handful of shared moral values and social norms. Any effort to select and rank rights must entail political choices. ${ }^{29}$

The danger of human rights is that these political selections are then wrapped in the mantle of universalism. The transcendent claim of universal human rights pretends to reside outside of the politics of a given situation. ${ }^{30}$ Once endowed with human rights status, these choices are elevated above politics and, more importantly, beyond political critique. This weakens available responses, as legal approaches to social problems are narrow in scope and muted in tone. A political response to a political problem may be more powerful than a legal response.

It is important to remember that this universal framing is simply the current incarnation of international human rights law. It

definitively resolve the closer issues-the ones that remain the subject of serious political debate.").

26. ICCPR, supra note 16 , at art. 6(1)

27. Indeed, this debate is found within the ICCPR itself. Compare ICCPR, supra note 16, at art. 6(2) (permitting the death penalty for serious crimes), with Second Optional Protocol to the International Covenant on Civil and Political Rights, Aiming at the Abolition of the Death Penalty, G.A. Res. 44/128, U.N. Doc. A/RES/44/128 (Dec. 15, 1989).

28. See MUTUA, supra note 24, at 65 ("Many states have been alien to their populations and it is questionable whether they represent those populations ....”).

29. See Koskeniemmi, supra note 15, at 55 (noting that rights exist at the core of politics); MUTUA, supra note 24, at 66 (explaining that "[t]he difficulty lies in the emphasis placed on certain rights, their ranking within that universe, and ultimately the political character of the state required or implied by that conception of rights").

30. Cooper, supra note 21, at 474-75; Koskeniemmi, supra note 15, at 55. 
is possible to imagine an approach to human rights that would make more modest claims, explicitly acknowledging the political nature of the rights selected and the disputed content of relevant norms. The process by which the content of human rights law is determinedtreaty text and treaty body decisions-could also be designed in a more pluralist and inclusive way. ${ }^{31}$ Such alterations would sap some of the power of international human rights law and would be politically challenging to implement. Grand claims to universality are problematic but are not necessarily inherent to international human rights law.

\section{Human Rights Law Obscures Global Inequality}

An individualist approach to human rights assumes a world of autonomous individual actors able to access and exercise rights on an equal footing. ${ }^{32}$ This assumption of autonomy fails to recognize inequities in the global distribution of wealth, power, opportunity, and social goods that render the playing field uneven. ${ }^{33}$ In fact, the focus on "discrete and specific social injustices" against individuals may serve to obscure political and economic inequality on a global scale. ${ }^{34}$ From a more radical perspective, the individualist focus of human rights has been equated with empire, containing as it does declarations of equality within a differentiated and hierarchical structure. ${ }^{35}$

The individualist approach of human rights treaties and their interpretive bodies diverts attention from their development and operation "in a global context with large inequalities of political power." 36 The structure of the individual-rights-based regime emphasizes legal sources and avenues for implementation; larger questions about the political and economic roots of inequality have no

31. For a discussion of how such a process might be designed, see, for example, Ramji-Nogales, supra note 20.

32. See UDHR, supra note 11, at art. 1 (stating that "[a]ll human beings are born free and equal in dignity and in rights"); see also Cooper, supra note 21, at 479 (describing the British anti-slavery movement in the early nineteenth century as offering a universalized vision of "a particular sort of rights: that of the individual to act as a free agent in a world consisting of other autonomous individuals. It was the violation of such autonomy that represented a violation of rights."); TONY EVANS, THE Politics of Human Rights: A Global PeRSPECTIVE 30-31 (2005) (describing how "the [human rights] tradition of individualism continues to obscure our vision of structural causes of violations").

33. Martha Albertson Fineman, The Vulnerable Subject and the Responsive State, 60 EMORY L.J. 251, 253 (2010).

34. Richard THOMPSON Ford, Rights GONE Wrong 21 (2011); Kennedy, supra note 13, at 11; Martti Koskenniemi, 'The Lady Doth Protest Too Much': Kosovo, and the Turn to Ethics in International Law, 65 MoD. L. REV. 159, 172-73 (2002); Cass Sunstein, Rights and Their Critics, 70 NotRE DAME L. REV. 727, 743-44 (1995).

35. Cooper, supra note 21, at 484.

36. BEITZ, supra note 20, at 201. 
place in the analysis. ${ }^{37}$ The individualist focus of human rights law is also manifested in its prioritizing of negative rights, or rights that require people to refrain from acting in certain ways, over positive rights, or rights that require people to take action. ${ }^{38}$ Efforts to ameliorate structural inequality would require concerted action, while an individualist approach to rights is content with preventing interference with individual autonomy. Finally, individualism elevates civil and political rights, which can be exercised by the autonomous actor, over economic and social rights, which might open the door to concerns about distributive inequality.

The situation of undocumented migrants helps to illustrate how the individualist focus of the human rights system distracts the attention and resources of the international community, including human rights treaty bodies and NGOs tasked with enforcing these rights, away from systemic global injustice. International human rights treaties and their interpretive bodies have limited the individual rights available to undocumented migrants. It is hardly an acceptable response within the human rights regime to argue that developed countries both help to create the conditions that force these migrants to leave their countries in search of work and benefit economically from their labor. Such arguments fall well outside the scope of human rights treaties. The focus narrows to the question of whether specific human rights obligations attach to migrants seeking jobs in the developed world, entirely avoiding the structural inequality in the international order that leaves these migrants with little other choice.

Through its individualist focus, the human rights regime may thus protect the geopolitical order and the interests of powerful global actors at the expense of vulnerable populations. ${ }^{39}$ The individual human rights regime helps powerful nations evade discussions of the economic relationships between developing and developed nations that create and perpetuate inequality. ${ }^{40}$ Moreover, the individualist nature of human rights discourse, unmoored from concerns of global inequity, enables citizens of prosperous nations to perceive and portray their right to territorial security as a moral entitlement while denying that right to noncitizens, particularly the undocumented. ${ }^{41}$

37. EVANs, supra note 32, at 13-14, 38-39.

38. HENRY SHue, BASIC Rights: Subsistence, AFFluence, AND U.S. Foreign POLICY 36 (1996).

39. See BEITZ, supra note 20, at 201-03 (suggesting that "[h]uman rights are vehicles of "moral imperialism"').

40. Id. at 171-79, 203-09.

41. Catherine Dauvergne, Making People Illegal: What Globalization MEANS FOR MIGRATION AND LAW 17 (2008) (arguing that "[m]any citizens of prosperous states experience their right to enter and remain there as a morally imbued entitlement, rather than an accident of birth. Those who seek to enter can therefore be cast as 'rorters' seeking to unjustly exploit the system or circumvent the (just) rules that confine them to poorer states with fewer life chances."). 
This boundaries-based approach to rights obscures the reality that social cooperation and economic benefits cross borders, which as a result should not "mark the limits of social obligations." 42

Addressing the "obscuring global inequality" critique would require a radical transformation of international human rights law. It is possible to imagine a set of rights that could foreground distributional inequity, just as a system of human rights could require adjudicators to incorporate questions of global inequality into their decisions. Such an approach to international human rights would look less individualist and more communitarian. That is not the system currently in place, but it is a conceivable alternative vision of human rights.

\section{Human Rights Law Crowds Out Alternative Worldviews}

The individualist approach to human rights conceptualizes the individual as the primary unit in society. This depiction of social relations is at odds with the organizational norms of many societies and offers an incomplete representation of other societies. Individualism overlooks the importance of group identity and solidarity in resolving social problems. It also focuses attention on harm to specific individuals, obscuring the broader societal ramifications of vulnerability. As a result, human rights approaches may impede alternative emancipatory strategies that may be more effective. ${ }^{43}$

Ongoing debates over cultural relativism and human rights suggest that in many societies, people are conceptualized primarily as members of groups rather than as autonomous individuals. ${ }^{44}$ Though some of these arguments have been crudely framed and controversial, they offer a deeper truth that the individualist focus of human rights law ignores. This is the social constructionist perspective-the idea that individuals are autonomous but exist within concrete social

42. Charles R. Beitz, Political Theory and International RElations 151, 161 (reprinted 1999); Seyla Benhabib, The Rights of Others: Aliens, Residents AND CITIZENS 1005 (2004) (agreeing with Beitz and Pogge's "liberal cosmopolitan vision that in a world of radical, and not merely accidental and transitory, interdependencies among peoples, our distributive obligations go well beyond the natural duty of assistance").

43. See FORD, supra note 34, at 24-26 (2011) (arguing that civil rights have "occupied the field of social justice, crowding out alternative ways of thinking and new solutions"); KENNEDY, supra note 13, at 8-9 (explaining that the "institutional and political hegemony [of human rights] makes other valuable, often more valuable, emancipatory strategies less available").

44. MUTUA, supra note 24, at 65; RAJAGOPAL, supra note 23, at 213 (describing the Asian values critique of human rights as "the communitarian and obligationoriented cultures of East Asia generate particular Asian values that are incompatible with western, individualistic human-rights notions, and in fact generate different conceptions of justice, solidarity, and governance that 'work' as effectively as (if not better than) those found in the West"). 
relations that develop through continual interaction. ${ }^{45}$ This conception of society, which moves us beyond viewing individual human beings as rights bearers and economic actors, creates expectations of mutual interaction and mutual sustenance. ${ }^{46}$ An individualist approach to human rights overlooks the importance and mutually beneficial nature of such relationships.

For many people, group identification is an important component of identity. For example, an undocumented migrant might view herself as a congregant of an Evangelical church, as a caretaker to her elderly parents or grandchildren, and as a member of a community group that seeks to improve the situation of immigrants. These group identities may be more important to her than her individual identity, and the relative importance of those identities may, of course, shift over time. Yet the atomistic nature of human rights law prioritizes her individual attributes, in particular her lack of lawful immigration status, in determining the level of protection she should receive. Legal conceptions that do not match up with an individual's self-conception risk undermining the legitimacy of the law. Moreover, such groups are important to society in numerous ways, and human rights law's failure to recognize these social ties may damage both the groups and society more broadly.

Grouping is a vital component of civil society. As individuals cohere around common beliefs or needs, they form movements that are important in ameliorating their condition, the condition of others, and society as a whole. ${ }^{47}$ For vulnerable individuals, group identity and solidarity may be crucial tools in improving their situation. ${ }^{48}$ As one person, it may be difficult to make one's voice heard, but as a member of a broader coalition, it may be possible to express common concerns in the political sphere. The public presentation of these concerns may bring forward yet more individuals impacted by them or may help to raise awareness on behalf of those who are unable to do so themselves. Broader society benefits from a robust exchange of ideas and from ensuring that marginalized groups are incorporated into the political process rather than being permanently sidelined. Human rights law depicts people as autonomous individuals rather than members of groups ("undocumented migrant" rather than "church-goer, caretaker, and community activist"), failing to account for social ties in legal decisions that in turn narrow the public discourse.

45. See Neil Stammers, Human Rights and Power, 41 PoL. Stud. 70, 72-73 (1993) (explaining that individuals "stand as subjects/individuals in concrete social relations which develop by process").

46. Cooper, supra note 21 , at 475.

47. Diane Marie Amann, Group Mentality, Expressivism, and Genocide, 2 INT'L CRIM. L. REV. 93, 128 (2002).

48. KENNEDY, supra note 13 , at 16 . 
In particular, as Hiroshi Motomura has noted, international human rights law focuses on the rights of noncitizens without thinking about "ways in which immigration-related decisions profoundly affect those individuals who are already citizenmembers." 49 Societies in the developed world are a dense tapestry of citizens and noncitizens who live in the same neighborhoods, attend the same schools, work together, pray together, and marry and raise children together. Viewed in context, one can more easily see that undocumented migrants benefit our societies in numerous ways. Instead of conceptualizing these migrants as charity cases, who deserve protection out of only altruism or guilt, we can begin to understand that their vulnerability threatens us all. ${ }^{\mathbf{5 0}}$

International human rights law has made real and lasting contributions to alleviating vulnerability across the globe. The universal individualist approach, however, has shortcomings. The scope of human rights law is limited, and the suffering of vulnerable populations that falls outside these limits is erased from the popular discourse. The content of human rights law is inherently subject to political choices, which is dangerous because human rights law depicts itself as transcending the political fray. The focus on individual rights obscures broader structural inequality that is often the root source of vulnerability. Finally, the emphasis on the individual obscures the importance of social ties for the vulnerable as well as for the rest of society. The next Part considers how these flaws have impacted one particularly vulnerable group: undocumented migrants.

\section{Human Rights LAW AND Undocumented MigRants}

\section{A. Being Undocumented}

The term undocumented migrant is challenging to define, as immigration status is not fixed. Over their lifetime, based on changes in the law or their personal situation, immigrants may gain and lose documented status. For the purposes of this Article, the term undocumented refers to individuals without any lawful immigration status or any special claim to protection against deportation. ${ }^{51}$ It may

49. Hiroshi Motomura, Federalism, International Human Rights, and Immigration Exceptionalism, 70 U. CoLO. L. REV. 1390, 1391 (1999).

50. Id.

51. Another approach would be to define undocumented migrants as individuals who entered without authorization onto state territory or who stayed beyond their authorized period of residence. Elspeth Guild, Who Is an Irregular Migrant?, in IrRegular Migration and Human Rights: TheOretical, European AND International PERspectives 3 (Barbara Bogusz et al. eds., 2004). I prefer the narrower definition laid out above in the text as some individuals in Elspeth Guild's 
be helpful to think of immigration status as a spectrum from citizen to lawfully present noncitizen to undocumented noncitizen. The human rights that attach to the first two groups are generally quite similar, with the exception of certain political rights such as voting. ${ }^{\mathbf{2}}$ The third group can be split apart into those without lawful status who might have a special claim to protection, such as asylum seekers and applicants for protection under the United Nations Convention Against Torture and other Cruel, Inhuman, or Degrading Treatment or Punishment (CAT), and those without any such claim. This Article focuses on the latter group, which is far more numerous than the former and to which far fewer crucial rights apply.

Individuals fleeing civil or political harm in the form of persecution or torture are able to access special forms of protection under the United Nations Convention Relating to the Status of Refugees and the United Nations Convention Against Torture. ${ }^{53}$ If such migrants are able to establish that they fear certain types of mistreatment in their home countries, either at the hands of their government or because of their political beliefs, religion, race, nationality, or social group membership (e.g., gender or sexual orientation), they are entitled to remain in their host country whether or not they entered lawfully or maintained lawful immigration status after entry. ${ }^{54}$ But undocumented migrants fleeing poverty or economic harm have no equivalent claim to protection.

Within the group of undocumented noncitizens without special claims to protection, two further clarifications remain. First, these migrants are normally thought of as having no claim to lawful immigration status, which is true for the majority of this group. There is, however, a subset of undocumented migrants who may have a lawful avenue to remain of which they are unaware (other than asylum or CAT protection). This Article classifies that subset as undocumented, as that is their status prior to adjudication of their immigration status, and human rights law would therefore treat them as unlawfully present. Second, an increasing number of noncitizens with lawful immigration status are subject to loss of

definition may have claims to asylum or CAT protection, which endows them with not only a substantive defense to deportation but also greater procedural rights than other undocumented migrants. Id. at 17.

52. See, e.g., Special Rapporteur. Final Rep. on the Prevention of Discrimination: The Rights of Non-Citizens, U.N. Comm. Human Rights, Subcomm. on the Promotion and Protection of Human Rights, Economic and Social Council,

U.N. Doc. E/CN.4/Sub.2/2003/23, ๆ 18 (May 26, 2003) (by Mr. David Weissbrodt) ("[T] he Civil and Political Covenant permits States to draw distinctions between citizens and non-citizens with respect to two categories of rights: political rights explicitly guaranteed to citizens and freedom of movement.").

53. Convention Relating to the Status of Refugees, supra note 17; Convention Against Torture, supra note 17.

54. Convention Relating to the Status of Refugees, supra note 17. 
status and deportation as a result of criminal convictions. ${ }^{55}$ This Article generally classifies that group of noncitizens as documented, at least with respect to assessment at the time of their deportation hearing. ${ }^{56}$ Again, human rights law would view this group as lawfully present and therefore entitled to certain rights until they are deported. There may of course be exceptions, for example, if such a noncitizen remains in the host country unlawfully after the deportation order is entered. These complexities serve as a reminder that immigration status is not stable and that noncitizens may shift back and forth between lawful and unlawful status over time.

Though it is difficult to accurately measure flows of undocumented migrants, the most reliable estimates range between thirty and forty million worldwide in $2005 .{ }^{57}$ The United States hosts the largest absolute number of undocumented migrants. In 2011, there were an estimated eleven million undocumented migrants in the United States. ${ }^{58}$ The previous year, undocumented migrants represented an estimated 3.7 percent of the U.S. population. ${ }^{59}$ The numbers are substantially smaller in the European Union, where the data are less reliable. ${ }^{60}$ In 2008, there were an estimated 1.9 to 3.8 million undocumented migrants in the European Union, representing 0.39 to 0.77 percent of the population. ${ }^{61}$ Numbers in Australia are smaller yet, with an estimated 61,000 undocumented migrants in 2012 , approximately 0.3 percent of the population. ${ }^{62}$

55. See, e.g., Juliet Stumpf, The Crimmigration Crisis: Immigrants, Crime, and Sovereign Power, 56 AM. U. L. REV. 367 (2006) (describing the criminalization of immigration law); Daniel Kanstroom, Post-Deportation Human Rights Law: Aspiration, Oxymoron, or Necessity?, 3 STAN. J. Civ. RTS. \& CiV. LiBeRTIES 195, 204 (2007) (explaining the modern trend of crime-based deportation).

56. The loss of lawful immigration status as a result of criminal convictions is of course an important problem but requires a different focus and assessment in deportation decisions. This Article focuses on the rights of those who had no lawful status at the start of deportation proceedings.

57. Demetrios G. Papademetriou, The Global Struggle with Illegal Migration: No End in Sight, MigRATION POL'Y INST. (Sept. 1, 2005), http://www.migration information.org/Feature/display.cfm?ID=336 [http://perma.cc/ TAH9-SZGV] (archived Feb. 17, 2014).

58. Jeffrey Passel \& D'Vera Cohn, Unauthorized Immigrants: 11.1 Million in 2011, PEW HISPANIC CENTER (Dec. 6, 2012), http://www.pewhispanic.org/ 2012/12/06/unauthorized-immigrants-11-1-million-in-2011/ [http://perma.cc/3GB9-ZV6X] (archived Feb. 17, 2014).

59. Paul Taylor et al., Pew Hispanic Center, Unauthorized Immigrants: Length of Residency, Patterns of Parenthood 1, 5 (Dec. 1, 2011), available at http://www.pewhispanic.org/files/2011/12/Unauthorized-Characteristics.pdf [http://perma.cc/93ZX-BQQ3] (archived Feb. 17, 2014).

60. These numbers also fluctuate more than the numbers in the United States because of more frequent regularization policies. See Papademetriou, supra note 57.

61. European Comm’n, Clandestino ProjeCt: Final Report 12 (Nov. 2009).

62. Fact Sheet 87: Initiatives to Combat Illegal Work in Australia, AUSTRALIAN GOV'T, DEP'T, OF IMMIGRATION AND CITIZENSHIP, http://www.immi.gov.au/media/factsheets/87illegal.htm\#c (last visited Jan. 15, 2014) [http://perma.cc/EJM6-2FL2] (archived Feb. 12, 2014); Australia Revealed as 2011 Census Data Is Released, 
Developed nations are not the only migrant-receiving states. In 2013, South Africa hosted an estimated 500,000 to one million undocumented migrants, which is about 1.8 percent of the total population-a smaller absolute number but larger share of the population than the European Union. ${ }^{63}$ Mexico hosted an estimated one million undocumented migrants in 2005. ${ }^{64}$ Thailand was also home to an estimated population of over one million undocumented migrants in 2012. ${ }^{65}$ From Kazakhstan to Kuwait, migrant workers, often undocumented, span the globe in search of gainful employment. ${ }^{66}$

If it were possible to sum up the situation of undocumented migrants in one word, that word would be "vulnerable." 67 Because undocumented migrants do not have the educational background or skills or the financial means to avail themselves of legal migration routes, they are forced to take the riskiest means of transportation and entry into their destination country. Migrants coming to the United States from points south face miles of harsh desert populated by unscrupulous traffickers and violent gangs; many die each year attempting the passage. ${ }^{68}$ Migrants to Australia and Europe often face risky boat journeys over violent seas in rickety vessels; many lose their lives at sea. ${ }^{69}$ Most must leave their families, including very

AUSTRALIAN BUREAU OF STATistics (June 21, 2012), http://www.abs.gov.au/websitedbs/ censushome.nsf/home/CO-56 [http://perma.cc/RUH5-Q57H] (archived Feb. 17, 2014).

63. John Campbell, Misconceptions About Cross Border Migration in South Africa, Council on Foreign Relations Blog: AfRica in TRANSition (Feb. 20, 2013), http://blogs.cfr.org/campbell/2013/02/20/misconceptions-about-cross-border-migrationin-south-africa/ [http://perma.cc/37FS-UEBP] (archived Feb. 17, 2014) (describing the estimated number of illegal immigrants); Statistics South Africa, Mid-Year Population Estimates 2013 (May 14, 2013), available at http://www.statssa.gov.za/ publications/P0302/P03022013.pdf [http://perma.cc/6QG3-MV7L] (archived Feb. 17, 2014) (stating the total population).

64. Papademetriou, supra note 57.

65. Thailand's Illegal Immigrants: A Deadly Cocktail, The Economist (Mar. 2, 2013), http://www.economist.com/news/asia/21572800-long-standing-worker-abusesget-some-serious-attention-deadly-cocktail [http://perma.cc/V6MS-JL2C] (archived Feb. $17,2014)$.

66. See, e.g., HUM. RTS. WATCH, Rights ON THE LinE 8-10 (2010) (reporting on human rights abuses against migrants).

67. See, e.g. Jorge A. Bustamante, Immigrants' Vulnerability as Subjects of Human Rights, 36 INT'L MigRATION REV. 333, 340 (2002) (describing the threats faced by and precarious status of migrants around the world).

68. See, e.g., Jaya Ramji-Nogales, Human Rights at the Border, InTLAWGRRLS (June 12, 2007, 3:28 PM), http://www.intlawgrrls.com/2007/06/human-rights-atborder.html [http://perma.cc/55J9-36TM] (archived Feb. 17, 2014) (describing the deaths of many migrants attempting to enter the United States through the southern border).

69. See, e.g.,Comm'n for Hum. Rts., Council of Europe, The Human Rights of Irregular Migrants in Europe 4 (CommDH/Issue Paper, 2007) [hereinafter Irregular Migrants in Europe] (describing a small boat from North Africa rescued by Italian authorities, in which 15 out of 85 passengers had survived, as "a scene from Dante's Inferno"). 
young children, behind in their home country in order to undertake their dangerous voyage. ${ }^{\mathbf{7 0}}$

The vulnerability continues once these undocumented migrants arrive in their host country. Many who are caught entering the country are detained in prison-like conditions, sometimes alongside criminal detainees. ${ }^{71}$ Those who manage to enter face exploitation at the hands of employers, traffickers, members of their community, and even law enforcement. ${ }^{72}$ Because of their fears that they will be deported if they report these abuses to the authorities, undocumented migrants often have no recourse. ${ }^{73}$ Employers are able to withhold wages and provide subhuman working conditions; landlords are able to extort exorbitant rents; traffickers can demand usurious rates and abusive forms of payment including forced labor and prostitution; and law enforcement officers can abuse them physically and sexually with impunity. ${ }^{74}$ As one commentator notes, these migrants live a

70. See, e.g., Women/Children/Families Left Behind, GLOBAL Migration GROUP, http://www.globalmigrationgroup.org/theme/womenchildrenfamilies-left-behind [http://perma.cc/HBU4-3RCN] (archived Mar. 7, 2014).

71. See, e.g., Elisabetta Povoledo, Italy's Migrant Detention Centers Are Cruel, Rights Groups Say, N.Y. TIMES (June 5, 2013), http://www.nytimes.com/2013/06/05/ world/europe/italys-migrant-detention-centers-are-cruel-rights-groups-say.html?_r=0 [http://perma.cc/6Z4Q-MPPR] (archived Feb. 19, 2014) (reporting that undocumented migrants are held in prison-like conditions).

72. See Matthew J. Gibney, Outside the Protection of the Law: The Situation of Irregular Migrants in Europe 21 (Refugee Studies Center, Working Paper No. 6, 2000), available at http://www.rsc.ox.ac.uk/publications/working-papers-folder_contents/ RSCworkingpaper6.pdf/view [http://perma.cc/492P-FFRZ] (archived Feb. 19, 2014) (describing how illegal immigrants are vulnerable to exploitation); RIGHTS ON THE LINE, supra note 66 , at 1 .

73. See, e.g., Linda Bosniak, Human Rights, State Sovereignty and the Protection of Undocumented Migrants Under the International Migrant Workers' Convention, in IRREgular Migration AND Human Rights: TheORETICAL, EuROPEAN AND International Perspectives 311 (Barbara Bogusz et al. eds., 2004); HuM. RTs. Watch, Cultivating Fear: The Vulnerability of ImMigrant FarmWorkers IN THE US TO SEXUAL VIOLENCE AND SEXUAL HARASSMENT 49 (2012).

74. See, e.g., An Outrage in East Haven, N.Y. Times (Jan. 26, 2012), http://www.nytimes.com/2012/01/27/opinion/an-outrage-in-east-haven-conn.html

[http://perma.cc/7PMX-MYCV] (archived Feb. 19, 2014) (reporting that police in East Haven physically abused the undocumented immigrant population); Thailand's Illegal Immigrants, supra note 65 (reporting that undocumented workers are smuggled into Thailand and then sold into debt bondage in factories and low-skilled jobs, where they suffer physical abuse, are unpaid, and sometimes murdered); Mark Lacey, Mother's Call Led to Rescue of 10 Children from Smugglers in Phoenix, Officials Say, N.Y. TIMES (Dec. 4, 2010), http://www.nytimes.com/2010/12/05/us/05arizona.html [http://perma.cc/KN85UXUK] (archived Feb. 19, 2014) (reporting that smugglers held undocumented migrant children for ransom, threatening to rape and kill three girls ages 12-15 unless their mother paid them \$10,000); Irregular Migrants in Europe, supra note 69 (describing physical and sexual abuse inflicted by Montenegran politicians, judges, police, and civil servants upon a smuggled Moldovan woman forced to work as a prostitute and the sale of five-year-old Serbian Roma children in Italy for forced labor and prostitution); HUM. RTS. WATch, Fields of PERIL: Child LABOR IN US AGRICUlture 67-70 (2010) (describing reluctance of undocumented child migrant workers to complain about abusive labor practices, including sexual assault, for fear of deportation); Special 
"rightsless existence without the basic protections of criminal and civil law and with no legal avenues by which to assert an entitlement to humane treatment." 75 Because of their vulnerable status, undocumented migrants are usually unable to assert even those rights that exist on paper. ${ }^{76}$

In addition to the exploitation and abuse they suffer because of their immigration status, undocumented migrants face the constant specter of deportation. In many cases, removal from their host country will tear undocumented migrants away from family and community ties built over many years. ${ }^{77} \mathrm{~A}$ typical contemporary story is that of Ms. Garcia, a forty-year-old U.S. citizen whose undocumented husband has been living in the United States since he was 10 years old. They have spent 8 years and over $\$ 50,000$ unsuccessfully attempting to regularize his immigration status. Their two U.S.-citizen children "live on edge, fearing they could be separated from their father at any time."78 For children whose parents are deported, the toll is tremendous. Some lose their parents entirely, ending up in foster care. Others end up with a single parent who has suddenly become the sole provider of financial support and childcare. This often results in food and housing insecurity, and the concomitant emotional stress has seriously detrimental impacts on child development. ${ }^{79}$

Even without close family ties, deportation can be a harsh punishment for undocumented migrants who have resided in their host states for many years. In a recent example, Hong Kong's highest court ruled that a Filipina woman who had lived in Hong Kong as a

Rapporteur of the Commission, Human Rights of Migrants, I 11, G.A., U.N. Doc. A/58/275 (Aug. 12, 2003) (by Gabriela Rodriguez Pizarro) ("The impossibility of denouncing abusive practices by employers for fear of arrest and deportation and the lack of any social and labour protection,... make irregular migrants vulnerable to exploitation and all types of abuses...."); PLATFORM FOR INT'L COOPERATION ON Undocumented MigRants, PICUM's MaIn Concerns About the Fundamental RightS OF UNDOCUMENTED MigRANTS IN EUROPE: 2010, at 35-37 (2010) (describing vulnerability of undocumented workers, including undocumented migrant whose employer threw away his arm after it was cut off by a kneading machine and another whose employer dragged him into the street and left him there after the worker had suffered a heart attack).

75. Gibney, supra note 72 , at 21.

76. Cooper, supra note 21, at 475, 485.

77. See, e.g., Hum. RTS. WATCH, Forced Apart: FAmilies SeParated AND Immigrants HaRmed By United States Deportation Policy (2007); Florida

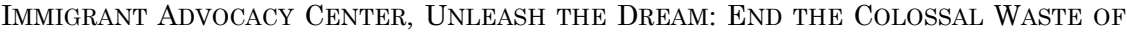
YOUNG IMMIGRANT TALENT (2010).

78. Julia Preston, U.S. Citizens Join Illegal Immigrants in Pressing Lawmakers for Change, N.Y. TIMES (Mar. 13, 2013), http://www.nytimes.com/ 2013/03/14/us/politics/us-citizens-join-illegal-immigrants-in-pressing-lawmakers-forchange.html?_r=0 [http://perma.cc/XNR9-UAGT] (archived Feb. 19, 2014).

79. JOANNA DREBy, CENTER FOR AMERICAN PROGRESS, How TODAY'S IMMIGRATION ENFORCEMENT POLICIES IMPACT CHILDREN, FAMILIES, AND COMMUNitiEs: A VIEW FROM THE GROUND 18-19 (2012). 
domestic worker for over 25 years was not entitled to permanent residency. ${ }^{80}$ Like all human beings, undocumented migrants form friendships, participate in community groups, and become woven into the fabric of society over time. The destabilizing potential of losing these ties, even if it does not include the loss of children and other close family members, is a serious harm.

This Article focuses on these two central challenges of being undocumented: the inability to seek protection against exploitation and the rupture of family and community ties through deportation. Of course there are other rights, such as health care and education, that undocumented migrants would prioritize. The argument of this Article, expounded further in later Parts, is that it is impossible for migrants to exercise important substantive rights when they are subject to discrimination and deportation without recourse. These vulnerabilities must first be addressed so that undocumented migrants have the ability to claim other rights. The next subpart attempts to translate these fundamental concerns into the language of rights in order to determine the extent to which international human rights law recognizes and protects undocumented migrants against these harms. In other words, this translation enables the measurement of universal individualism on its own terms-Does it really lay out a shared set of rights applicable individually to all human beings?

\section{B. Human Rights from the Perspective of Undocumented Migrants}

Taking international human rights law on its own terms, this Article first asks whether it lives up to its promises of universal individualism. Does human rights law offer a set of shared fundamental rights applicable individually to all human beings? This Article seeks to answer that question through the case study of undocumented migrants, asking whether human rights law protects the rights that they consider most essential. The most accurate method of responding would be through empirical measurement of undocumented migrants' perspectives on which rights they view as fundamental. Unfortunately, available data on the preferences of undocumented migrants are insufficient to support any claims concerning shared fundamental values. ${ }^{81}$

80. Keith Bradsher, Hong Kong Court Denies Residency to Domestics, N.Y. TIMES (Mar. 25, 2013), http://www.nytimes.com/2013/03/26/world/asia/hong-kong-courtdenies-foreign-domestic-helpers-right-to-permanent-residency.html [http://perma.cc/HT4R-7D5Y] (archived Feb. 19, 2014).

81. While robust political polling data are captured throughout the developed world, and in some parts of the developing world, few, if any, instruments separate out the preferences expressed by undocumented migrants. The Pew Hispanic Center provides the closest approximation of undocumented migrant preferences by exploring the preferences of Latinos who were not lawful residents in the United States. These 
In the absence of empirical data, this subpart takes as a starting point the dual challenges of exploitation and rupture of family and community ties. As long as these vulnerabilities exist, undocumented migrants will find it difficult to exercise any other rights. As a result, this Article argues that combating discrimination and deportation are fundamental concerns for undocumented migrants. In order to test how human rights law fares in addressing the problems of exploitation and rupture of social ties, this subpart translates these vulnerabilities into four potential rights-family unity, nondiscrimination based on immigration status, procedural due process in immigration proceedings, and territorial security. The following subpart assesses whether human rights law adequately protects these rights.

As described in the previous subpart, undocumented migrants face exploitation in many realms and have limited options for redressing this mistreatment. There are two central reasons for undocumented migrants' inability to protect themselves against exploitation. Discrimination or exclusion based on immigration status-in particular, on the lack of lawful status-is considered acceptable under domestic and international law. It is widely acknowledged that sovereign states maintain the right to treat differently people without lawful immigration status. This concept of differential treatment as acceptable when it comes to immigration status is reinforced by undocumented migrants' fear of deportation. These migrants know that they could be deported at any time, and, as a result, often fail to seek protection against mistreatment. Those who exploit migrants are able to capitalize on this fear by threatening deportation if the migrants report them to authorities. In other words, actual limits on protection combine with real and perceived obstacles to enforcement to create an environment in which undocumented migrants are susceptible to exploitation.

Undocumented migrants also suffer from the rupture of family and community ties through deportation-a harm that is insufficiently acknowledged as a rights violation and against which they have few protections. International and domestic laws fail to frame these ties as entitlements, instead focusing on the migrant's lack of lawful status. The lack of redress is caused in part by the limited procedural protections available in immigration proceedings. Immigration adjudicators, for example, may not be able to take into

studies are, obviously, far from comprehensive assessments of the views of undocumented migrants more broadly. See, e.g., TAYLOR ET AL., supra note 59; JEFFREY Passel \& PaUl TAYlor, Pew Hispanic CENTER, UnAUthorized ImMigrants AND THeIR U.S.-BORN CHILDREN (Aug. 11, 2010), available at http://www.pewhispanic.org/ iles/reports/125.pdf [http://perma.cc/Y9FA-RB73] (archived Feb. 19, 2014); see also RANDY CAPps, JAMEs D. BACHMEIER, MichaEl Fix \& JeNnifER VAN HoOK, Migration POLICy Institute, A Demographic, Socioeconomic, and Health CARE Profile of UNAUTHORIZED IMMIGRANTS IN THE UNITED STATES 3 (May 2013). 
account family or community ties when issuing deportation orders. ${ }^{82}$ The unavailability of relief is also caused by the absence of any right to remain, even for undocumented migrants who have resided in a country for many years and for some migrants whose close family members are nationals of the country in which they reside.

If undocumented migrants had a voice in the construction of international human rights law, they would likely view widespread exploitation and rupture of family and community ties as fundamental problems they face. Translated into the language of rights, these concerns could be addressed through rights to family unity, nondiscrimination based on immigration status, procedural due process in immigration proceedings, and territorial security. But as the next subpart demonstrates, while international human rights law claims to represent shared universal values, it does not prioritize these rights that are crucial to protecting undocumented migrants. In other words, international human rights law's failure to recognize these rights demonstrates the failures of its claims to universalism.

\section{The Contested Content of Human Rights Law}

Human rights law has been defined by one of its most prominent scholars, Louis Henkin, as "those benefits deemed essential for individual well-being, dignity, and fulfillment, and that reflect a common sense of justice, fairness, and decency." 83 This definition immediately gives rise to the questions of how to determine what is essential and whose vision of common sense should prevail. The situation of undocumented migrants provides an example of just how difficult it can be to find common ground when competing political interests underlie questions about the scope of human rights law. The varying levels of protection accorded to undocumented migrants, a group with little political voice, remind us that human rights law is a site of political contestation rather than a fixed set of transcendental norms.

This subpart assesses the availability of four rights that might attach to undocumented migrants under international human rights law: the right to be free of discrimination based on immigration status, the right to due process in deportation proceedings, the right to family unity, and the right to territorial security. It explores the levels of contestation over each right, determining to what extent the perspective of undocumented migrants is represented in international and regional human rights law. Though these rights are conceptually distinct, there remains some overlap between them, with, for

82. See, e.g., Immigration and Nationality Act $\S 242(\mathrm{a})(2)(\mathrm{C}), 8$ U.S.C. $\S 1252(\mathrm{a})(2)(\mathrm{C})$ (2000); Antiterrorism and Effective Death Penalty Act of 1996, Pub. L. No. 104-132, §§ 440(a)-(d), 110 Stat. 1214.

83. HENKIN, supra note 11, at 2. 
example, the right to family unity giving rise in some cases to a right to procedural due process in immigration proceedings and in other cases a right to territorial security.

It is important to note that this subpart assesses human rights law on its own terms. There are many reasonable arguments as to why sovereign states should have the ability to exclude or differentially treat undocumented migrants. ${ }^{84}$ This Article does not address those claims here, as they are not relevant to this project. This project is focused on the story that human rights law tells about itself, and whether that story is accurate. Human rights law does not claim to offer a set of rights that are carefully balanced with the interests of sovereign states and represent the shared fundamental values of specific societies or subsets of those societies. Nor does it say that the rights contained within its canon are applicable only to certain individuals. Human rights law claims to represent universal shared values and to offer individualized protections to all human beings. Those are the claims that this Article tests.

This Article measures human rights as those elaborated on paper, in treaties and soft law, not as those enforced on the ground. Apart from being much easier to quantify, the nonexistence of rights on paper speaks directly to international human rights law's commitment to protecting undocumented migrants. It is of course impossible to enforce human rights law through legal mechanisms on the ground if specific rights do not exist in the relevant human rights instruments or have been interpreted out of those treaties. As we shall see, that is often the story of the rights of undocumented migrants to be free from discrimination based on immigration status, to procedural due process in immigration proceedings, and to territorial security.

This discussion of international human rights law looks to two types of sources: treaties, or hard law, and decisions by and statements of interpretive bodies, or soft law. 85 Treaties are considered binding on all states who have signed and ratified them. ${ }^{86}$

84. See, e.g., David Cole, Are Foreign Nationals Entitled to the Same Constitutional Rights as Citizens?, 25 T. JEFFERSON L. REV. 367, 384-86 (2003) (laying out some of these arguments).

85. Statute of the International Court of Justice art. 38(1), June 26, 1945, 993 U.N.T.S. (listing as sources of international law: "a. international conventions, whether general or particular, establishing rules expressly recognized by the contesting states; b. international custom, as evidence of a general practice accepted as law; c. the general principles of law recognized by civilized nations; $d$. subject to the provisions of Article 59, judicial decisions and the teachings of the most highly qualified publicists of the various nations, as subsidiary means for the determination of rules of law.”). A determination of the custom and general principles of human rights law applicable to undocumented migrants is beyond the scope of this Article, which focuses on the first and last types of sources.

86. Vienna Convention on the Law of Treaties art. 11, May 23, 1969, 1155 U.N.T.S. 331, 8 I.L.M. 679. 
Decisions by interpretive bodies are binding on the parties to the dispute in question (who have subjected themselves to the jurisdiction of that body) but are not precedential sources of law beyond the case at hand. ${ }^{87}$ These decisions, along with statements promulgated by interpretive bodies in the form of "general comments" or "conclusions," are considered persuasive evidence of rules of international law. ${ }^{88}$

In terms of binding treaty law, this Article focuses primarily on the International Convention on Civil and Political Rights (ICCPR). While the International Convention on the Protection of the Rights of All Migrant Workers and Members of Their Families (Migrant Worker Convention) might seem a more obvious starting point for a discussion of the rights of undocumented migrants, that treaty, which was finalized in 1990 and came into force in 2003, has been ratified by only forty-six states, all of which could fairly be characterized as primarily migrant-sending states. ${ }^{89}$ As a result, the treaty has little binding power over primarily migrant-receiving states. The Article also discusses relevant provisions of the International Covenant on Economic, Social and Cultural Rights (ICESCR) and the International Convention on the Elimination of All Forms of Racism, as well as relevant International Labor Organization (ILO) treaties.

In terms of soft law, this Article focuses on individual decisions and general comments issued by the ICCPR's implementing body, the United Nations Human Rights Committee (HRC). ${ }^{90}$ It also discusses differences between this body of law and regional human rights law developed by the European Court of Human Rights and the InterAmerican Commission and Court of Human Rights, ${ }^{91}$ which are the

87. See, e.g., Tara J. Melish, From Paradox to Subsidiarity: The United States and Human Rights Treaty Bodies, 34 YALE J. INT'L L. 389, 404-05 (2009).

88. Id.

89. International Convention on the Protection of the Rights of All Migrant Workers and Members of Their Families, July 1, 2003, 2220 U.N.T.S. 3 [hereinafter Migrant Workers Convention]; see also InT'L COMM'N OF JURISTS, MigRATION AND InTERnAtional HUMAN Rights, PRACTICIONERS GUIDE No. 6, at 129 (2011) [hereinafter JURISTS], available at http://icj.wpengine.netdna-cdn.com/wpcontent/uploads/ 2012/08/migration-and-international-human-rights-law-practitionersguide-2011-eng.pdf [http://perma.cc/UY3V-XR5P] (archived Feb. 19, 2014) (noting that few developed countries likely to be destination states for migrants have joined the Convention).

90. Individual complaints may be brought only against States Parties that have accepted the jurisdiction of the Committee in an optional protocol to the ICCPR. Optional Protocol to the International Covenant on Civil and Political Rights, Dec. 16, 1966, U.N. Doc. A/6316, 999 U.N.T.S. 302. The United States, for example, has not accepted this individual jurisdiction, so it cannot be subject to such complaints. Status of the Optional Protocol to the International Covenant on Civil and Political Rights, United NATiOns TREATY COLlection, http://treaties.un.org/Pages/ViewDetails.aspx? src=IND\&mtdsg_no=IV-5\&chapter=4\&lang=en [http://perma.cc/9353-BA32 ] (archived Feb. 19, 2014).

91. The Inter-American Commission on Human Rights is composed of seven members nominated by Member States and elected individually by the Council of the 
bodies that interpret the European Convention on Human Rights and the Inter-American Convention on Human Rights. ${ }^{92}$ The discussion below elaborates on the sites of contestation in human rights law relevant to undocumented migrants, starting with the least contested, and least available, rights and moving to the most contested rights.

\section{Territorial Security}

The right to territorial security does not exist in international human rights law; indeed, it is frequently disavowed in treaties and soft law. This right, as proposed in this Article, would enable undocumented migrants with substantial community ties to regularize their status in their host state. This is not a claim to "open borders," or a right to entry at will, but a right that would enable migrants who have lived in a host state for long enough to develop deep social attachments to obtain lawful immigration status in that state $^{93}$ Such a right need not be absolute and could, for example, contain exclusions for serious threats to national security and public order. ${ }^{94}$ Even so modified, this right is nowhere to be found in the

Organization of American States to serve a four-year term. The Commission investigates individual human rights petitions, reports on human rights in member states, and makes site visits to member states. The Inter-American Court of Human Rights is composed of seven judges elected for a six-year term. Only the Commission and States Parties to the American Convention on the Rights and Duties of Man are authorized to submit cases to the Court. Basic Documents in the Inter-American System, INTER-AM. COMM'N ON HUM. RTS., http://www.oas.org/en/iachr/mandate/Basics/ intro.asp [http://perma.cc/V8L9-HHZN] (archived Feb. 19, 2014).

92. The African Commission on Human and Peoples' Rights is not discussed in the text as it has no specific regional instrument protecting migrants and its relevant case law discusses only lawful migrants. Special Rapporteur on Refugees, Asylum Seekers, Migrants, and Displaced Persons, Report of the Mechanism of the Special Rapporteur on the Rights of Refugees, Asylum Seekers, and Internally Displaced and Migrants in Africa Since Its Creation 9 18, Afr. Comm. Hum. \& Peoples' Rts., 52nd Ordinary Session, (Oct. 9-22, 2012) (by Madam Maya Sahli-Fadel). The African Commission on Human and Peoples' Rights' Special Rapporteur on the Rights of Refugees, Asylum Seekers, Migrants, and Internally Displaced has not created any soft law relevant to the protection of undocumented migrants. Id.

93. Cf. Linda Bosniak, Ethical Territoriality and the Rights of Immigrants, 1 AMSTERDAM L.F. 1, 3 (2008) (discussing the ethical territoriality approach, by which "once someone is in geographic territory of the state, that person must, for most basic purposes, be treated as fully in").

94. A recent poll found that nearly seven in ten Americans would support a law allowing undocumented migrants in the United States to obtain lawful permanent residence if they met certain requirements. Sixty-five percent of those surveyed would support a law allowing undocumented migrants to become U.S. citizens if they met certain requirements. Elizabeth Mendes, Americans Favor Giving Illegal Immigrants a Chance to Stay: Immigrant Work Visa Program More Divisive, GALLUP POLITICs (Apr. 12, 2013), http://www.gallup.com/poll/161765/americans-favor-giving-illegal-immigrantschance-stay.aspx [http://perma.cc/6KL7-2SSN] (archived Feb. 19, 2014) (poll conducted Apr. 9-10, 2013). 
ICCPR or any of the other international or regional treaties applicable to undocumented migrants. In other words, there is no contestation around the existence of this right in treaty law; it does not exist anywhere.

The right to territorial security is an essential precondition for undocumented migrants to exercise other rights. Without territorial security, undocumented migrants are vulnerable to deportation at any time. This vulnerability enables employers and others to exploit undocumented migrants simply by threatening to turn them over to immigration enforcement authorities. Undocumented migrants often fail to report threats and other mistreatment because they are so fearful of deportation. Without the right to territorial security, all of the other rights accorded undocumented migrants in international human rights treaties become simply words on paper.

Despite the importance of this right, international human rights treaties and treaty interpretive bodies have repeatedly determined that there is no right to territorial security for undocumented migrants. The United Nations Human Rights Committee has specifically stated that the ICCPR "does not recognize the rights of aliens to . . . reside in the territory of a State party." 95 Even the Migrant Worker Convention, often thought of as the treaty most protective of migrant rights, explicitly states that it does not offer any right to remain, or in its terms, "right to regularization" for undocumented migrants or their families. ${ }^{96}$ Similarly, the InterAmerican Court of Human Rights and the Inter-American Commission on Human Rights (IACHR), which have consistently extended a broad range of human rights to undocumented migrants, have found that states have the right to control the residence of and expel migrants on their territory ${ }^{97}$

95. General Comment 15: The Position of Aliens Under the Covenant I 5, U.N. Hum. Rts. Comm., 27th Sess., Apr. 11, 1986 [hereinafter UNHRC, General Comment 15]; Manfred NowaK, U.N. COVEnant on CIVIL AND Political Rights: CCPR COMMENTARY 51 (1993) (noting that because "a right to enter and reside in a State Party is not ensured to aliens ..., the effective enjoyment of Covenant rights can be limited de facto by threatening expulsion"). While UNHRC General Comment 15 suggests that nondiscrimination and respect for family life might give rise to the right to enter or reside, this has not been the Human Rights Committee's interpretation, as discussed further below. See also Declaration on the Human Rights of Individuals Who Are Not Nationals of the Country in Which They Live, G.A. Res. 40/144, art. 2(1), U.N. Doc. A/RES/40/144 (Dec. 13, 1985) ("Nothing in this Declaration shall be interpreted as legitimizing the illegal entry into and presence in a State of any alien, nor shall any provision be interpreted as restricting the right of any State to promulgate laws and regulations concerning the entry of aliens and the terms and conditions of their stay or to establish differences between nationals and aliens.").

96. Migrant Workers Convention, supra note 89, at art. 35.

97. See e.g., Juridical Condition and Rights of the Undocumented Migrants, Advisory Opinion OC-18/03, Inter-Am. Ct. H.R., I 169 (Sept. 17, 2003) [hereinafter Advisory Opinion OC-18/03]; Wayne Smith, Hugo Armendariz et al. v. United States, Inter-Am Comm'n H.R. No. 81/10, ๆ 49 (July 12, 2010). 
Article 12(4) of the ICCPR, which states that "[n]o one shall be arbitrarily deprived of the right to enter his own country," might have presented a potential source for grounding this right but has not been read so expansively. Though the Human Rights Committee has interpreted "his own country" to be broader than "country of nationality," including those who are stateless, ${ }^{98}$ it has refused to extend this interpretation to offer the right to remain to lawful permanent residents, let alone undocumented migrants. ${ }^{99}$

\section{Procedural Due Process in Deportation Proceedings}

International human rights treaty bodies have found that procedural due process rights do not apply to undocumented migrants in immigration proceedings, though the Inter-American Commission on Human Rights has challenged this interpretation of human rights law. Procedural due process rights represent a range of protections that might include notice of the allegations against a migrant, a meaningful opportunity to be heard, the right to confront the evidence and witnesses against a migrant, a neutral decision maker, judicial review, the right to government-appointed counsel, and the right to government-funded translation. ${ }^{100}$ Both the UN Human Rights Committee and the European Court of Human Rights have held that these rights apply only to documented migrants in immigration proceedings.

The procedural due process rights laid out in the ICCPR do not apply to all undocumented migrants in deportation proceedings. ${ }^{101}$ Only noncitizens "lawfully in the territory" are awarded the right to an expulsion decision "in accordance with law" and to submit reasons against their expulsion. ${ }^{102}$ The UN Human Rights Committee has

98. Stewart v. Canada, Comm. No. 538/1993, U.N. Hum. Rts. Comm., 58th Sess., Oct. 21-Nov. 8, 1996, ๆ 12.5, U.N. Doc. CCPR/C/58/D/538/1993 (Dec. 16, 1996) (Charles E. Stewart).

99. See generally id.; Canepa v. Canada, Comm. No. 558/1993, U.N. Hum. Rts. Comm., 59th Sess., Mar. 24-Apr. 11, 1997, U.N. Doc. CCPR/C/59/D/558/1993 (June 20, 1997); Winata v. Australia, Comm. No. 930/2000, U.N. Hum. Rts. Comm., ๆ 6.3, U.N. Doc. CCPR/C/72/D/930/2000 (July 26, 2001).

100. Many undocumented migrants are detained during their deportation process, making it much harder to access these procedural due process rights. Unfortunately, a full exploration of the case law relating to detention of undocumented migrants is beyond the scope of this Article. For a discussion of the applicable human rights law, see, for example, JURISTS, supra note 89, at 147-91.

101. Id. at 128 (noting that undocumented migrants are relatively unprotected in terms of procedural protections under the ICCPR and the European Convention on Human Rights).

102. ICCPR, supra note 16, at art. 13. The UN Human Rights Committee has stated that the procedural due process rights in Article 13 should be interpreted in light of Article 14's guarantees of impartiality, fairness, and equality of arms. See, e.g., Ahani v. Canada, Comm. No. 1051/2002, U.N. Hum. Rts. Comm., 80th Sess., Mar. 15Apr. 2, 2004, ๆ 10.9, U.N. Doc. CCPR/C/80/D/1051/2002 (June 15, 2004) (Mansour 
interpreted this language to apply to noncitizens who challenge the validity of the deportation order against them but not to undocumented migrants more broadly. ${ }^{103}$ Similarly, the procedural due process protections of the European Convention on Human Rights apply only to noncitizens lawfully present. ${ }^{104}$

The more specific procedural due process rights to equal access to courts, equality of arms, and nondiscrimination attach in all "determination[s] of . . . rights and obligations in a suit at law"; 105 in other words, "whenever domestic law entrusts a judicial body with a judicial task." 106 While the HRC has interpreted "a suit at law" to cover several areas of administrative law, it has explicitly stated both in individual decisions and in its general comment on its due process clause that this provision does not include deportation procedures. ${ }^{\mathbf{1 0 7}}$ None of the other international or regional treaties discussed in this Part explicitly provides for the right to procedural due process in immigration proceedings.

The Inter-American system has contested this narrow construction of human rights law. ${ }^{108}$ In Smith, Armendariz, et al. $v$. United States, the Inter-American Commission on Human Rights determined not only that the American Declaration of the Rights and Duties of Man ensures procedural due process rights in immigration

Ahani); Everett v. Spain, Comm. No. 961/2000, U.N. Hum. Rts. Comm., 81st Sess., July 5-30, 2004, U.N. Doc. CCPR/C/81/D/961/2000 (Aug. 26, 2004) (Ronald Everett); Taghi Khadje v. Netherlands, Comm. No. 1438/2005, U.N. Hum. Rts. Comm., 88th Sess., Oct. 16-Nov. 3, 2006, U.N. Doc. CCPR/C/88/D/1438/2005 (Nov. 15, 2006) (Hamid Reza Taghi Khadje). As a result, procedural due process rights are imported into immigration proceedings only where the applicant is lawfully present.

103. UNHRC, General Comment 15, supra note 95, I 6 ("[I]f the legality of an alien's entry or stay is in dispute, any decision on this point leading to his expulsion or deportation ought to be taken in accordance with article $13 \ldots$. An alien must be given full facilities for pursuing his remedy against expulsion so that this right will in all the circumstances of his case be an effective one.").

104. Council of Europe, Protocol No. 7 to the European Convention for the Protection of Human Rights and Fundamental Freedoms art. 1, E.T.S. No. 155 (Nov. 22, 1984); European Court of Human Rights, Nolan v. Russia, App. No. 2512/04, \ 48 (Feb. 12, 2009).

105. ICCPR, supra note 16, at art. 14(1). In practice, undocumented migrants may be unaware of potential legal avenues to remain so this standard is insufficiently protective of their due process rights.

106. General Comment 32, Article 14: Right to Equality Before Courts and Tribunals and to a Fair Trial 9 7-8, U.N. Hum. Rts. Comm., 90th Sess., July 9-27, 2007, U.N. Doc. CCPR/C/GC/32 (2007).

107. Id. I 17; P.K. v. Canada, Comm. No. 1234/2003, U.N. Hum. Rts. Comm., 89th Sess., Mar. 12-30, 2007, ๆ 7.4-7.5, U.N. Doc. CCPR/C/89/D/1234/2003 (Mar. 20, 2007); Zündel v. Canada, Comm. No. 1341/2005, U.N. Hum. Rts. Comm., 78th Sess., July 14-Aug. 8, 2003, ๆ $6.7-6.8$, U.N. Doc. CCPR/C/89/D/1341/2005 (July 27, 2003) (Ernst Zündel).

108. The African Commission on Human and People's Rights has also found a right to due process in deportation proceedings, but none of the cases decided to date have involved undocumented migrants. For a discussion of these cases, see JURISTS, supra note 89 , at $135-36$. 
proceedings but also that "in the context of immigration proceedings that include the sanction of deportation, ... heightened due process protections apply." ${ }^{109}$ In this case, two lawful permanent residents of the United States were subject to mandatory deportation because they had been convicted of minor drug-related offenses. ${ }^{110}$ Because the relevant U.S. law did not permit the applicants to present humanitarian arguments (including the length of their residence in the United States and the hardship of their deportation on family members), the Commission found a violation of the American Declaration's procedural due process requirements. ${ }^{111}$

There may also be contestation on the horizon from an international interpretive body. In 2012, the Drafting Committee of the United Nations International Law Commission provisionally adopted draft articles relating to the expulsion of aliens. ${ }^{112}$ These articles, which have yet to be submitted to the United Nations General Assembly for codification, enumerate specific procedural rights that must be accorded to noncitizens subject to expulsion, including the right to notice and a hearing, the right to representation, and the right to free interpretation. These rights apply to undocumented migrants who have been present in the relevant state for six months or longer. ${ }^{113}$ These draft articles will at best become soft law standards, if approved by the United Nations General Assembly, but like the Inter-American Commission's decision, they suggest a broader approach to the procedural due process rights of undocumented migrants in deportation proceedings. ${ }^{114}$

109. Wayne Smith, Hugo Armendariz et al. v. United States, Inter-Am Comm'n H.R. No. 81/10, 63 (July 12, 2010); American Declaration of the Rights and Duties of Man, O.A.S. Res. XXX, adopted by the Ninth International Conference of American States (1948), art. XXVI, available at http://www.cidh.oas.org/Basicos/English/ Basic2.american\%20Declaration.htm [http://perma.cc/8TT6-QZ7D] (archived Feb. 19, 2014).

110. Mr. Smith was convicted of possession and attempted distribution of cocaine, serving three years in prison. Mr. Armendariz was convicted of possession of cocaine for sale, possession of drug paraphernalia, and hindering prosecution. Neither man had a subsequent conviction and both were employed and paying taxes. Smith, Armendariz, Inter-Am Comm'n H.R. No. 81/10, at ๆ 13-14, 20-21.

111. Id. ๆ 63.

112. Expulsion of Aliens, Int'l Law Comm'n, 64th Sess., May 7, June 1, July 2, Aug 3, 2012, U.N. Doc. No. A/CN.4/L/797 (May 24, 2012) [hereinafter Expulsion of Aliens]. The International Law Commission is comprised of thirty-four international legal experts who focus on the progressive development of international law by preparing draft conventions, as well as the codification of international law by publishing reports that may be adopted by the U.N. General Assembly. Introduction, INT'L LAW COMM'N, http://www.un.org/law/ilc/ [http://legal.un.org/ilc/ilcintro.htm] (archived Feb. 19, 2014).

113. Expulsion of Aliens, supra note 112, at 7.

114. The African Commission on Human and Peoples' Rights has upheld the right to a deportation hearing before mass expulsion. Union Inter-Africaine des Droits de l'Homme v. Angola, Comm. No. 159/96, ๆ 20 Afr. Comm'n Hum. \& Peoples' Rts., 
3. Nondiscrimination Based on Immigration Status

Though international human rights law protects undocumented migrants from discrimination on numerous grounds, the right to nondiscrimination based on immigration status is limited. Yet undocumented migrants face discrimination precisely because they do not have lawful immigration status. This marker of vulnerability enables employers, landlords, hospitals, and other social service providers to exclude migrants from fair treatment, protection, and benefits on the basis of their immigration status. Undocumented migrants can receive unequal pay because they are not authorized to work, can have their housing applications rejected for a lack of official identity documentation, can be refused health care because they are ineligible for national health insurance programs, and can be excluded from pension and welfare programs. ${ }^{115}$ Immigration status also authorizes states to keep undocumented migrants outside of the voting polity. ${ }^{116}$ While this might seem an obvious sovereign right, it is not a foregone conclusion that migrants with substantial community ties should be any less entitled to vote than citizens. If we free our imagination from the sovereignty paradigm, political community might be bounded along social ties rather than physical borders.

Though nondiscrimination is one of its foundational rights, the ICCPR does not explicitly prohibit discrimination based on immigration status. ${ }^{117}$ The ICCPR contains two clauses enumerating the right to nondiscrimination based on numerous grounds, including race and national origin. Neither includes immigration status or even nationality in its list of protected statuses. ${ }^{118}$ In fact, the drafters of

11th ACHPR AAR Annex II (1997-1998) (Nov. 11, 1997), available at http://www.worldcourts.com/achpr/eng/decisions/1997.11.11_UIADH_v_Angola.htm [http://perma.cc/9CEG-FCX3] (archived Feb. 19, 2014).

115. See, e.g., U.S DeP’t Health \& Hum. SERvs., Summary of Immigrant ELIGIBILITY RESTRICTIONS UNDER CURRENT LAW (Feb. 25, 2009), available at http://aspe.hhs.gov/hsp/immigration/restrictions-sum.shtml [http://perma.cc/Y5B52C7V] (archived Feb. 19, 2014); Tanya Broder \& Jonathan Blazer, Overview of Immigrant Eligibility for Federal Programs, NAT'L IMMig. LAW CENTER (Oct. 2011), http://www.nilc.org/overview-immeligfedprograms.html [http://perma.cc/N6PG-KDRN] (archived Feb. 19, 2014).

116. See. e.g., Register to Vote, USA.GOV, http://www.usa.gov/Citizen/Topics/ Voting/Register.shtml (last updated Feb. 20, 2014) [http://perma.cc/7SVY-SE8M] (archived Feb. 19, 2014).

117. UNHRC, General Comment 15, supra note 95, If 7 (listing the rights attaching to noncitizens once they enter a State Party); see also Statement of the Global Migration Group on the Human Rights of Migrants in Irregular Situation, U.N. HuM. RTS. CoMm'N (Sept. 30, 2010), http://www.ohchr.org/EN/NewsEvents/Pages/ DisplayNews.aspx?NewsID=10396\&LangID=E [http://perma.cc/4LZV-KJP4] (archived Feb. 19, 2014).

118. ICCPR, supra note 16, at art. 2(1) (requiring States Parties to ensure all rights in the Convention without distinction based on race, colour, sex, language, religion, political or other opinion, national or social origin, property, birth, or other 
the ICCPR specifically excluded nationality from the grounds of nondiscrimination. ${ }^{119}$ The treaty drafters appear to have been concerned about being required to extend certain civic, political, and property rights to noncitizens. ${ }^{\mathbf{1 2 0}}$ Rather than crafting a narrow exception based on these concerns, they created a human rights treaty that permits discrimination based on immigration status or nationality.

Both nondiscrimination provisions include a catch-all "other status" provision that might have been interpreted to include immigration status. The UN Human Rights Committee has not used these provisions to extend the grounds of nondiscrimination to protect undocumented migrants. Indeed, the language of the Committee's General Comment on the Position of Aliens under the ICCPR could be read to exclude undocumented migrants from its protections: "[O]nce aliens are allowed to enter the territory of a State party they are entitled to the rights set out in the Covenant." 121

Similarly, the Migrant Worker Convention contains no explicit prohibition on discrimination based on immigration status. ${ }^{122}$ Indeed, the treaty delineates certain rights-including the rights to family unity; liberty of movement; trade union rights; participation in public affairs; equality of treatment as to education, housing, and other social services; and freedom from double taxation-as inapplicable to undocumented migrants. ${ }^{123}$

In the same vein, the International Labor Organization (ILO)'s 1949 Migration for Employment Convention offers protection against discrimination relating to employment and social security only to

status); $i d$. at art. 26 (requiring equal protection of the law on the same grounds); NowAK, supra note 95, at 479.

119. See NowAK, supra note 95, at 51 (noting that the drafters of Article 26 "pointed out that the general prohibition of discrimination did not prohibit each and every type of unequal treatment of aliens" and that under Article 2(1), "unequal treatment of aliens is permissible only with respect to rights limited to nationals"); see also GAOR Official Records, Annotations on the Text of the Draft International Covenants on Human Rights ch. VI, § 181, U.N. Doc. A/2929 (July 1, 1955); GAOR, Draft International Covenants on Human Rights, Report of the Third Committee I 113, U.N.Doc. A/5000 (Dec. 5, 1961) [hereinafter Draft International Covenants on Human Rights] ("[I]t was generally felt that ... the denial of certain civic or political rights to aliens... [did not] constitute discrimination within the meaning of article $2[6] . ")$.

120. Draft International Covenants on Human Rights, supra note 119.

121. UNHRC, General Comment 15, supra note 95, ๆ 6 (emphasis added).

122. Migrant Workers Convention, supra note 89, at art. 1(1) ("The present Convention is applicable, except as otherwise provided hereafter, to all migrant workers and members of their families without distinction of any kind such as sex, race, colour, language, religion or conviction, political or other opinion, national, ethnic or social origin, nationality, age, economic position, property, marital status, birth or other status."). In any case, this Convention has been ratified by only thirty-five states, none of which are major migrant-receiving states.

123. Id. at arts. $36-56$. 
migrants lawfully in the territory of the State Party. ${ }^{124}$ European regional human rights law, in the form of the European Social Charter, is similarly narrow in its protections of undocumented migrants. ${ }^{125}$ While the ILO's 1975 Migrant Workers Convention provides for equal treatment for the undocumented with respect to rights arising out of past employment, it offers no right to equal opportunity and treatment with respect to employment for workers unlawfully present. ${ }^{126}$

The story is a bit more complicated when it comes to the ICESCR and the International Convention on the Elimination of All Forms of Racial Discrimination (CERD). The text of the ICESCR contains no explicit prohibition on discrimination based on immigration status. ${ }^{127}$ However, the treaty interpretive body, the Committee on Economic, Social, and Cultural Rights, has stated in its general comment that the rights laid out in the ICESCR apply to non-nationals regardless of immigration status. ${ }^{128}$ Somewhat ironically, CERD explicitly permits "distinctions, exclusions, restrictions or preferences made by a State Party to this Convention between citizens and non-citizens." 129 This strong treaty language has been modified by CERD's interpretive body, the Committee on the Elimination of Racial Discrimination, to permit differential treatment based on immigration status only if

124. Int'l Labor Org., Convention Concerning Migration for Employment, C097: Migration for Employment Convention (Revised), 1949 (No. 97), at art. 6 (Jan. 22, 1952), available at http://www.ilo.org/dyn/normlex/en/f?p=NORMLEXPUB:12100:0 ::NO::P12100_ILO_CODE:C097 [http://perma.cc/GK6A-PT9C] (archived Feb. 19, 2014). The same is true of the European Convention on the Legal Status of Migrant Workers (Article 1(1)), which does not cover any of the three rights on which this section focuses. Council of Europe, European Convention on the Legal Status of Migrant Workers, E.T.S. No. 093 (Nov. 24, 1977), available at http://conventions.coe.int/Treaty/en/ Treaties/Html/093.htm [http://perma.cc/SP8-5CZN] (archived Feb. 19, 2014).

125. Council of Europe, European Social Charter arts. 19(4-5), (7-9), Oct. 18, 1961, C.E.T.S. No. 035; JURISTS, supra note 89, at 235.

126. See Int'l Labor Org., Convention Concerning Migrations in Abusive Conditions and the Promotion of Equality of Opportunity and Treatment of Migrant Workers, at art. 9-10 (Dec. 9, 1978), available at http://www.ilo.org/dyn/normlex/en/f? p=NORMLEXPUB:12100:0::NO::P12100_ILO_CODE:C143 [http://perma.cc/C37A-NX2M] (archived Feb. 27, 2014) (encouraging each member to develop a policy of "equality of opportunity and treatment" for migrant workers who "are lawfully within its territory"). Rights arising out of past employment include remuneration, social security, and other benefits.

127. International Covenant on Economic, Social, and Cultural Rights art. 2(2), G.A. Res. 2200A (XXI), 993 U.N.T.S. 3 (Jan. 3, 1976) (prohibiting "discrimination of any kind as to race, colour, sex, language, religion, political or other opinion, national or social origin, property, birth or other status").

128. General Comment No. 20: Non-discrimination in Economic, Social and Cultural Rights, U.N. Comm. on Econ., Soc. \& Cultural Rts., 42d Sess., May 4-22, 2009, ๆ 30, U.N. Doc. E/C.12/GC/20, (July 2, 2009).

129. International Convention on the Elimination of All Forms of Racial Discrimination art. 1(2), G.A. Res. 2106 (XX), 660 U.N.T.S. 196 (Jan. 4, 1969). 
such treatment is proportional to the achievement of a legitimate aim. ${ }^{130}$

The Inter-American regional human rights system also contests the UN Human Rights Committee's interpretation of the right to nondiscrimination based on immigration status. Like the ICCPR, the right to nondiscrimination in the text of the American Convention on Human Rights does not list nationality or immigration status as a protected ground. ${ }^{131}$ However, the Inter-American Court of Human Rights has interpreted both the American Convention and the ICCPR differently than the HRC. In its Advisory Opinion on the Juridical Condition and Rights of Undocumented Migrants, the Inter-American Court found that regional and international human rights treaties prohibit Member States from discriminating against undocumented migrant workers in the terms and conditions of work. ${ }^{132}$ The court conceded that states have the right to refuse entry and employment, but held that once employed, jus cogens principles of equality and nondiscrimination entitle undocumented migrants to basic workplace protections. ${ }^{133}$

\section{Family Unity}

Family unity has been the most promising human rights avenue for undocumented migrants to attain substantive and procedural protections in deportation proceedings, though supportive case law is limited. Conceptually, the right to family unity might take two forms: the right to enter a country in order to be reunified with one's family as well as the right to remain in a country so as not to be separated from one's family. The soft law thus far focuses on the latter right.

130. Comm. on the Elimination of Racial Discrimination, General Recommendation XXX: Discrimination Against Non Citizens $\uparrow 4$, U.N. Doc. CERD/C/64/Misc.11/rev.3 (Oct. 1, 2002). The Committee also recommends that public educational institutions be open to children of undocumented immigrants. Id. ๆ 29.

131. American Convention on Human Rights arts. 1(1), 24, OAS Treaty Series No. 36, 1144 U.N.T.S. 123 (July 18, 1978). The nondiscrimination clause of the American Convention is broader than that of the ICCPR, as the former states explicitly that it applies to "every human being," while the latter applies only to "all individuals within its territory and subject to its jurisdiction." Id. at art. 1(2); ICCPR, supra note 16, at art. 2(1). Though the language of the African Convention on Human Rights also does not explicitly include nationality, the African Commission on Human and Peoples' Rights has enumerated nationality as a protected ground in the context of mass deportations of foreign nationals. Union Inter-Africaine des Droits de l'Homme, supra note 114, , 18.

132. See generally Advisory Opinion OC-18/03, supra note 97. The court drew on not only OAS human rights instruments but also the ICCPR.

133. Id. ๆๆ 101, 119, 135-36, 159-60. 
Family has been interpreted relatively narrowly, emphasizing ties to spouses and minor children. ${ }^{134}$

The UN Human Rights Committee has, in two cases, grounded procedural due process protections for undocumented migrants in the right to family life and the right of citizen children to protection as a minor without discrimination.135 In both cases, though explicitly disclaiming the applicants' right to reside in Australia, the HRC ordered the government to reexamine its decision to deny their visa applications, offering some substantive relief as well. ${ }^{136}$ In the first case, while both applicants were undocumented, they had originally filed an asylum claim. ${ }^{137}$ In the second case, only one applicant was undocumented, and the other spouse was a citizen. ${ }^{138}$ In a third case, the HRC found inadmissible claims to family unity by undocumented migrants, one of whom had criminal convictions apparently of a nonviolent nature. ${ }^{139}$ While these decisions demonstrate the potential of human rights law to protect undocumented migrants, they also highlight some of the problems with human rights law discussed above-namely the distinctions it draws between "worthy" and "unworthy" migrants.

The first of these cases, Winata and Li v. Australia, decided in 2001 , is also the best known. The case was brought by two stateless individuals who were formerly Indonesian nationals. ${ }^{140}$ They had lived in Australia for 14 years, having arrived on valid visas that subsequently expired. ${ }^{141}$ Their thirteen-year-old son was born in Australia. ${ }^{142}$ After he acquired Australian citizenship, Winata and Li applied for asylum but their claims were denied.143 They then appealed their asylum claim and had a representative lodge an application for a parent visa at the Australian Embassy in Jakarta, Indonesia. ${ }^{144}$ When their asylum appeal was denied, Winata and $\mathrm{Li}$ requested that the government exercise humanitarian discretion based on hardship to their son of removal to Indonesia. ${ }^{145}$

134. See, e.g., Madafferi v. Australia, Comm. No. 1011/2001, U.N. Hum. Rts. Comm., 81st Sess., July 5-30, 2004, U.N. Doc. CCPR/C/81/D/1011/2001 (Aug. 26, 2004) (Francesco Madafferi \& Anna Maria Immacolata Madafferi).

135. Id.; Winata v. Australia, Comm. No. 930/2000, U.N. Hum. Rts. Comm., U.N. Doc. CCPR/C/72/D/930/2000 (July 26, 2001); ICCPR, supra note 16, at art. 17(1).

136. Madafferi, Comm. No. 1011/2001, ๆๆ 10-11; Winata, Comm. No. 930/2000, ๆ $8-10$.

137. Winata, Comm. No. 930/2000, 92.4 .

138. See generally Madafferi, Comm. No. 1011/2001.

139. Fernandes v. Netherlands, Communication No. 1513/2006, U.N. Hum. Rts. Comm., 93d Sess., July 7-25, 2008, ๆ 1, U.N. Doc. CCPR/C/93/D/1513/2006 (Aug. 6, 2008) (Vital Maria Fernandes et al.).

140. See generally Winata, Comm. No. 930/2000.

141. Id. I 2.1 .

142. Id.

143. $I d . ~ ๆ 2.2$.

144. Id. ๆ 2.3 .

145. Id. ๆ 2.4 . 
In its decision, the Human Rights Committee stated expressly that "aliens may not, as such, have the right to reside in the territory of a State party"146 and that "there is significant scope for States parties to enforce their immigration policy and to require departure of unlawfully present persons." 147 Given that the applicants had lived in Australia for over 14 years and that their child had grown up in Australia, the HRC found that the State Party was required to offer additional factors to justify their removal beyond simple enforcement of its immigration laws. ${ }^{148}$ Otherwise, their removal would constitute arbitrary interference with the family in violation of the ICCPR. ${ }^{149} \mathrm{In}$ particular, the HRC held that Australia should refrain from removing Winata and $\mathrm{Li}$ until their applications for parent visas were examined. ${ }^{150}$ Notably, the applicants had a viable route to lawful status; though they were technically undocumented, the HRC did not have to step outside Australia's immigration laws to find a legal avenue that would allow them to remain.

The same was true in the case of Madafferi $v$. Australia, decided 3 years later. Madafferi, an Italian citizen, arrived in Australia on a valid tourist visa in 1989.151 Four months after that visa expired, he married an Australian citizen, with whom he eventually had four citizen children. ${ }^{152}$ Madafferi believed that his marriage automatically granted him residence status. ${ }^{153} \mathrm{He}$ later learned that it did not and applied for a spouse visa in $1996 .{ }^{154}$ On that application, Madafferi disclosed that he had served 2 years in prison in Italy before arriving in Australia. ${ }^{155} \mathrm{He}$ later learned that he faced further sentences handed down in absentia in Italy and disclosed those sentences as well. ${ }^{156}$ While the Australian government was processing Madafferi's visa application, the Italian authorities ordered that the in absentia sentences be extinguished, some immediately and some within 2 years. ${ }^{157}$ Nevertheless, the Australian Minister of Immigration and Multicultural Affairs denied Madafferi's application for a permanent visa because of his prior

146. Id. ๆ 6.3 .

147. Id. ๆ 7.3

148. Id.

149. Id.; see ICCPR, supra note 16, at arts. 17(1), 23(1), 24(1) (ensuring the protection of the family and child against actions by the state).

150. Winata, Comm. No. 930/2000, ๆ 9.

151. Madafferi, Comm. No. 1011/2001, \ 2.1.

152. Id. ๆ 2.2 .

153. Id.

154. Id. ๆ 2.3 .

155. Id.

156. Id.

157. Id. ๆ 2.6 . 
convictions and outstanding prison term in Italy and placed him in indefinite detention. ${ }^{158}$

Examining Madafferi's claim of arbitrary interference with family life, the HRC laid out a balancing test requiring assessment of the State Party's reasons for removal and the degree of hardship to the family resulting from such removal. ${ }^{159}$ Given that Madafferi had been married to his wife for 14 years and their oldest children were 13 and 11 years old, the Committee found that the Minister's reasons for removal were not sufficiently pressing and that his removal would thus constitute arbitrary interference with the family. ${ }^{160}$ The HRC ordered the Australian government to process Madafferi's application for a spouse visa with an eye to the State Party's obligation to protect his minor children. Similar to Winata and $L i$, Madafferi had a viable path to lawful immigration status, and the Minister's decision at issue ignored not only the holding of the Australian Administrative Appeals Tribunal but also the Italian government's extinction of his in absentia sentences. ${ }^{161}$

More recently, in Fernandes $v$. the Netherlands, the HRC found inadmissible a claim of arbitrary interference with family life by two undocumented Cape Verdean nationals residing in the Netherlands with three Dutch citizen children and one undocumented child. ${ }^{\mathbf{1 6 2}}$ After residing unlawfully in the Netherlands for some time, Fernandes applied for a residence permit. ${ }^{163}$ His application was rejected due to his criminal record; he had been convicted three times

158. Id. I 2.7. This decision overruled the Administrative Appeals Tribunal decision to require the Minister to reconsider his initial refusal of Mr. Madafferi's visa.

159. Id. ๆ 9.8.

160. Id.; ICCPR, supra note 16, at arts. 17(1), 23(1), 24(1).

161. In several cases before and after Madafferi and Winata and Li, the Human Rights Committee found no violation of the right to family life in deporting lawful permanent residents who had criminal convictions. Canepa v. Canada, Comm. No. 558/1993, U.N. Hum. Rts. Comm., 59th Sess., Mar. 24-Apr. 11, 1997, U.N. Doc. CCPR/C/59/D/558/1993 (June 20, 1997) (Italian citizen with permanent residence in Canada, where he had resided since age 5 with 37 convictions); Stewart v. Canada, Comm. No. 538/1993, U.N. Hum. Rts. Comm., 58th Sess., Oct. 21-Nov. 8, 1996, U.N. Doc. CCPR/C/58/D/538/1993 (Dec. 16, 1996) (Charles E. Stewart) (British citizen with permanent residence in Canada, where he had resided since age 7 with 42 , mostly petty, convictions, but some serious offences); Truong v. Canada, Comm. No. 743/1997, U.N. Hum. Rts. Comm., 77th Sess., U.N. Doc. CCPR/C/77/D/743/1997 (March 28, 2003) (Ngoc Si Truong) (stateless Vietnamese national with permanent residence in Canada, where he had resided since age 16 with three convictions, married to Vietnamese woman and having mother and two brothers in Vietnam); Zündel v. Canada, Comm. No. 1341/2005, U.N. Hum. Rts. Comm., 78th Sess., July 14-Aug. 8, 2003, U.N. Doc. CCPR/C/89/D/1341/2005 (July 27, 2003) (Ernst Zündel) (German citizen residing in Canada for 42 years as permanent resident; citizenship refused because Minister issued national security certificate).

162. Fernandes v. Netherlands, Communication No. 1513/2006, U.N. Hum. Rts. Comm., 93d Sess., July 7-25, 2008, ๆ 1 1, 6.3, U.N. Doc. CCPR/C/93/D/1513/2006 (Aug. 6,2008 ) (Vital Maria Fernandes et al.).

163. Id. $\lceil 2.4$. 
of violations of the Opium Act and the Road Traffic Act. ${ }^{164}$ Because the family argued only that the Dutch citizen children, who were eligible for Cape Verdean citizenship, would suffer hardship if they had to follow their parents to Cape Verde, the HRC found their claim to be insufficiently substantiated and therefore inadmissible. ${ }^{165}$ In at least three other cases, the HRC has found no violation of the right to family unity for permanent residents deported due to criminal convictions, even though two had minor citizen children, one had a citizen spouse, and the other had resided in the host country since the age of five. ${ }^{166}$

The European Court of Human Rights has a substantially larger body of cases drawing upon the right to family unity to strike down residence bans or deportation orders. The vast majority of these cases involved immigrants with lawful status who were ordered deported based on criminal convictions. ${ }^{167}$ In that group of cases, the court established a standard for determining violations of the right to family unity in deportation cases: whether the deportation order was necessary in a democratic society, meaning it must be justified by a pressing social need and proportionate to the aim pursued. ${ }^{168}$ The court was less likely to find a violation of the right to family unity

164. Id. ๆ 2.5 .

165. Id. ๆ 6.3 .

166. See, e.g., Canepa, Comm. No. 558/1993 (holding not available to lawful permanent resident residing in Canada since the age of five with parents and brother, where applicant had no spouse or children and was a drug addict convicted of several crimes); Stewart, Comm. No. 538/1993 (holding not available to lawful permanent resident residing in Canada with parents (including ill mother), mentally disabled brother, and two young children; applicant was an alcoholic with criminal record).

167. A.A. v. United Kingdom, 2011 Eur. Ct. H.R. 1345; Abdulaziz v. United Kingdom, App. Nos. 9214/80, 9473/81, 9474/81, 7 Eur. H.R. Rep. 471 (1985); Al-Nashif v. Bulgaria, App. No. 50963/99, Eur. Ct. H.R. (2002); Amrollahi v. Denmark, App. No. 56811/00, Eur. Ct. H.R. (2002); Baghli v. France, App. No. 34374/97, Eur. Ct. H.R. (1999); Bensaid v. United Kingdom, App. No. 44599/98, Eur. Ct. H.R. (2001); Berrehab v. Netherlands, App. No. 10730/84, 33 Eur. H.R. Rep. 322 (1988); Bouchelkia v. France, App. No. 23078/93, 25 Eur. H.R. Rep. 686 (1998); Boughanemi v. France, App. No. 22070/93, 22 Eur. H.R. Rep. 228 (1996); Boultif v. Switzerland, App. No. 54273/00, 33 Eur. H.R. Rep. 50 (2001); C. v. Belgium, App. No. 21794/93, 12 Eur. Ct. H.R. 915 (1996); Chair \& J.B. v. Germany, App. No. 69735/01, Eur. Ct. H.R. (2007); Ciliz v. Netherlands, App. No. 29192/95, Eur. Ct. H.R. (2000); El-Boujaidi v. France, 30 Eur. H.R. Rep. 223 (2000); Jakupovic v. Austria, App. No. 36757/97, 30 Eur. H.R. Rep. 27 (2003); Kaushal v. Bulgaria, App. No. 1537/08, Eur. Ct. H.R. (2010); Kaya v. Germany, App. No. 31753/02, Eur. Ct. H.R. (2007); Keles v. Germany, App. No. 32231/02, Eur. Ct. H.R. (2005); Kiyutin v. Russia, App. No. 2700/10, Eur. Ct. H.R. (2011); Lamguindaz v. United Kingdom, App. No. 16152/90, 17 Eur. H.R. Rep. 213 (1993); Lupsa v. Romania, App. No. 10337/04, 46 Eur. H.R. Rep. 36 (2006); Maslov v. Austria, App. No. 1638/03, 47 Eur. H.R. Rep. 20 (2007); Mehemi v. France, App. No. 25017/94, 20 Eur. H.R. Rep. 739 (1997); Mokrani v. France, App. No. 52206/99, 40 Eur. H.R. Rep. 5 (2003); Moustaquim v. Belguim, App. No. 12313/86, 13 Eur. H.R. Rep. 802 (1991); Nasri v. France, App. No. 19465/92, 21 Eur. H.R. Rep. 458 (1995); Radovanovic v. Austria, App. No. 42703/98, 41 Eur. H.R. Rep. 6 (2004); Sezen v. Netherlands, App. No. 50252/99, 43 Eur. H.R. Rep. 30 (2006); Üner v. Netherlands, No. 46410/99, 45 Eur. H.R. Rep. (2006).

168. Boultif, App. No. 54273/00, \ 48. 
when the applicant was convicted on drug-related or other serious charges and more likely to find a violation when the applicant had a citizen spouse and children or had resided in the country since early childhood. ${ }^{169}$ In the three cases involving undocumented migrants, no violation of the right to family life was found. ${ }^{\mathbf{1 7 0}}$

The Inter-American Commission on Human Rights established the right to family unity for lawfully present migrants in an individual decision. In Smith, Armendariz, et al., the IACHR found a violation of the applicants' right to family life because the impact of deportation on their families was not considered in their immigration proceedings. ${ }^{171}$ This right attached to the applicants even though they both had criminal convictions, albeit nonviolent drug offenses. In a report discussing the rights of immigrants in deportation proceedings, the IACHR further noted that the "best interests of a migrant parent's children must be factored into any removal decision." 172 Though the report is not binding law, it signals a willingness to interpret the right to family unity broadly.

Though the right to family life is the most promising of the protections available to undocumented migrants under human rights law discussed in this section, it remains contested in scope. Moreover, much of the relevant case law focuses on those who held or had a viable path to lawful status prior to deportation proceedings, rather than on undocumented migrants. Successful cases focused on more sympathetic undocumented migrants or solutions that did not push too hard substantively on the defending state.

Table 1: The Human Rights of Undocumented Migrants

\begin{tabular}{|c|c|c|c|c|}
\hline & $\begin{array}{c}\text { Territorial } \\
\text { Security }\end{array}$ & $\begin{array}{c}\text { Procedural } \\
\text { Due } \\
\text { Process: } \\
\text { Deportation } \\
\text { Proceedings }\end{array}$ & $\begin{array}{c}\text { Nondiscrimination: } \\
\text { Immigration Status }\end{array}$ & $\begin{array}{c}\text { Family } \\
\text { Unity }\end{array}$ \\
\hline $\begin{array}{c}\text { International } \\
\text { Law }\end{array}$ & Unavailable & Unavailable & $\begin{array}{c}\text { Contested (only under } \\
\text { ICESCR and CERD } \\
\text { soft law) }\end{array}$ & $\begin{array}{c}\text { Available } \\
\text { in some } \\
\text { cases }\end{array}$ \\
\hline $\begin{array}{c}\text { European } \\
\text { Regional Law }\end{array}$ & Unavailable & Unavailable & Unavailable & $\begin{array}{c}\text { Available } \\
\text { in some } \\
\text { cases }\end{array}$ \\
\hline $\begin{array}{c}\text { Latin } \\
\text { American } \\
\text { Regional Law }\end{array}$ & Unavailable & Available & $\begin{array}{c}\text { Available for } \\
\text { employment rights }\end{array}$ & \begin{tabular}{c} 
Available \\
\hline
\end{tabular} \\
\hline
\end{tabular}

169. Compare, Keles, App. No. 32231/02, with Baghli, App. No. 34374/97.

170. Benhebba v. France, App. No. 53441/99, Eur. Ct. H.R. (July 10, 2003); Boujlifa v. France, App. No. 25404/94, 30 E.H.R.R. 419 (Oct. 21, 1997); Dalia v. France, App. No. 26102/95, (2001) 33 E.H.R.R. 26 (Feb. 19, 1998).

171. Wayne Smith, Hugo Armendariz et al. v. United States, Inter-Am Comm'n H.R. No. 81/10, ๆ 59-60, 63 (July 12, 2010); American Declaration of the Rights and Duties of Man, supra note 109, at art. V.

172. INTER-AM. COMM'N ON HUM. RTS., REPORT ON IMMIGRATION IN THE UNITED States: Detention AND Due Process $\uparrow$ 98, (OEA/Ser.L/V/II, Doc. 78.10, 2010). 
Viewed as a schematic, the human rights law discussed in this Part does not offer robust protections to migrants seeking protection against exploitation and the rupture of family and community ties through deportation. Rights range from unavailable to available on a limited basis in international and European treaties and interpretive bodies, and are fully available only in Latin American instruments and interpretations. Notably, even the latter do not protect the right to territorial security.

To the reader, this may seem obvious. Why should undocumented migrants be afforded the right to territorial security? They are, after all, noncitizens without legal authorization to remain in their host country. But it is important to remember that this conception of immigration status is but a social construction. ${ }^{173}$ Undocumented migrants are human beings and their claims to residence and protection are created by other human beings. The next Part explores how immigration status has become so deeply defining of our rights and ability to protect ourselves and our families from exploitation and rupture.

\section{CONSTRUCTING VULNERABILITY: SOVEREIGNTY, GLOBALIZATION, AND HUMAN RIGHTS}

It is not a new argument to claim that the twin forces of sovereignty and globalization have been complicit in creating the undocumented migrant and her vulnerability. Less often explored is the role of human rights law in constructing this vulnerability. Most accounts by legal scholars focus on the role of human rights law in piercing sovereignty and combatting the harmful aspects of globalization. Others admit the failings of human rights law in protecting undocumented migrants but suggest its potential remains, if only we could tap into it. This Article argues that human rights law has not only failed to protect undocumented migrants but that the universal individualist approach is deeply interconnected with globalization and sovereignty in ways that contribute to the vulnerability of these migrants. This Part starts by tracing the history of the relationship between sovereignty and human rights, highlighting how sovereign interests molded the universal individualist approach. It then describes the relationship between

173. See, e.g., Bosniak, supra note 93, at 1 ("[F]rom a global perspective, assignment of citizenship status is morally quite arbitrary.”); Iris Marion Young, Responsibility and Global Justice: A Social Connection Model, 23 Soc. PHIL. \& POL'Y 102, 130 (2006) (suggesting that "a theory of global justice" should "adopt . . . a conception of responsibility that recognizes" that "[g]lobal social and economic processes bring individuals and institutions into ongoing structural connection with one another across national jurisdictions"). 
globalization and migration, demonstrating how universal individualism entrenches global inequality.

\section{A. History of Human Rights: Sovereignty Challenged?}

Most accounts portray human rights as an antidote to sovereignty, one that challenges the way governments treat their nationals within their own territory. Human rights law has certainly been successful in raising awareness of and combating sovereign abuses in many cases. But as some critical scholars have noted, the story does not end there. The role human rights law has played in challenging established political power structures, including sovereign control of territory, is significantly more complicated. In order to better understand these complexities, this subpart briefly explores the historical relationship between sovereignty and human rights law.

The emergence of human rights law is commonly depicted as a dramatic shift in international law away from a system of sovereign states-as the creation of norms that could, for the first time in many decades, tell a sovereign what to do within its own territory. International law was initially a system of natural law. ${ }^{174}$ Beginning in the sixteenth century, international law derived its supranational force from the moral authority of religion. ${ }^{175}$ In 1648 , however, the major European nations of the time signed the Peace of Westphalia, agreeing to respect the sovereignty of their respective territories. ${ }^{176}$ The conventional history asserts that post-Westphalia, the international legal order claimed no superior authority over the actions of sovereign states within their borders. In other words, the Westphalia regime elevated the state as absolute sovereign authority over what had come before-namely, religion as supranational moral authority. ${ }^{177}$

In the post-Westphalia world, international legal authorities promoted the idea that states had sovereign control over their borders. Emmerich de Vattel, one of the founders of the field of international law, explained in his foundational text The Law of Nations that while a person has the right to dwell somewhere on earth, a state has the right to refuse admission in order to protect

174. See Anthony Anghie, Imperialism, Sovereignty AND the Making of INTERNATIONAL LAW 17-18 (2004) (explaining that natural law replaced divine law and "was proclaimed to be the basis of the new international law").

175. See Leo Gross, The Peace of Westphalia, 1648-1948, 42 AM. J. INT'L L. 20, 39 (1948) ("[T]he Peace of Westphalia ... ushers in the era of sovereign absolutist states which recognized no superior authority.”).

176. David Held, Law of States, Law of Peoples: Three Models of Sovereignty, 8 LEGAL THEORY 1, 3 (2002).

177. See supra note 176 and accompanying text. 
itself. ${ }^{178}$ Vattel explained that states should not exclude noncitizens based on groundless and frivolous fears but could do so to prevent disease, for economic reasons, due to concerns over "corrupt manners," and to prevent disorder. ${ }^{179}$ Once a state had admitted a noncitizen, it then had the authority to impose any conditions "not absolutely intolerable." 180 The appropriate recourse for mistreatment of a noncitizen would be a complaint presented by the government of that individual's home country.

International human rights law, according to most historical accounts, arrived to challenge this idea that states could do whatever they wanted within their own borders. ${ }^{181}$ Yet the when of it is subject to much debate. Some scholars source international human rights back to the Enlightenment, while others focus on the French and American Revolutions. ${ }^{182}$ Most would date its beginnings to the international human rights treaties drafted as a response to the mass abuses perpetrated by the Nazi regime. ${ }^{183}$ More convincing arguments suggest that projects to pinpoint precisely a single origin are flawed. ${ }^{184}$ Starting from that perspective, this subpart explores the evolution of rights in international law, pointing to critical junctures that shaped the contours of human rights law as we know it today.

The seeds of an individual-rights-based framework for international law were arguably sown as early as the sixteenth century, prior to the Peace of Westphalia. In the mid-1500s, in order to justify the Spanish imperial expansion, Spanish religious scholars established the foundations of the modern liberal order. ${ }^{185}$ Their theories of individual rights of universal applicability endorsed "the basic contemporary forms of territorial government" and "private ownership" of property. ${ }^{186}$ The Spanish theologians of this era focused on commutative, or horizontal, justice between individual rights

178. EMmERICH DE VATTEL, THE LAW OF NATIONS, OR, PRINCIPLES OF THE LAW OF NATURE, ApPlied to THE CONDUCT AND AFFAirs OF NATIONS AND SOVEREIGNS 108-09, 181 (Book 1, §§ 229-31, Book 2, § 125) (1853).

179. Id.

180. Id. at 181 (Book 2, § 125).

181. See, e.g., supra note 9 and accompanying text.

182. For examples of such works, see LYNN HUNT, INVENTING HUMAN Rights: A History (2008); Micheline R. Ishay, THE History of HuMAN Rights: From ANCIENT TIMES TO THE GLOBALIZATION ERA (2008).

183. See Alston, supra note 10, at 2065 ("[T] modern histories of human rights is the United Nations Charter of 1945 and the Universal Declaration of Human Rights of 1948.”).

184. Id. at 2066.

185. See Martti Koskenniemi, Empire and International Law: The Real Spanish Contribution, 61 U. TORONTO L.J. 1, 12 (2011) ("The notions of dominium, ius gentium, and the bellum iustum were now deployed to give a legal and moral articulation to the transformations of early modernity that disturbed the consciences of contemporaries ....").

186. Id. at 14 . 
holders rather than distributive, or vertical, relations between the individual and the community. ${ }^{187}$ They assumed the universal validity of this frame rather than accounting for cultural or religious differences. ${ }^{188}$ In contrast to many accounts of the pre-Westphalian international legal regime, this view suggests that the early articulators of universal individualism endorsed a "powerful and long-standing type of informal imperial domination that is achieved through a worldwide pattern of acquisition and exchange of private property by which . . . formal state policies are also controlled, enabled, or undermined, as befits the global market." 189

A similar story can be told of the concepts of rights arising from the French and American Revolutions. The idea of a social contract that vested rights in the people rather than the crown was a radical challenge to the nature of extant state power. As such, it had to be grounded in the strong language of natural rights-of universal individualism-that preceded the creation of the state. Yet this conceptualization of the source of rights, and concomitant claims to inalienability and universality, did not map onto social or historical realities. ${ }^{190}$ States had been created through war or conquest, not out of the authority of the people. Natural rights were highly restricted in content and applied to a narrow subset of society; they were most definitely not universal in practice. ${ }^{191}$ The framework of rights that upended monarchical rule also separated the private or economic sphere from the public or political sphere. ${ }^{192}$ This new approach, justified as being in the interests of all people, in reality created new power relationships that benefited particular groups. ${ }^{193}$

The international human rights treaties drafted in the wake of the Second World War inherited these historical flaws. This new human rights regime assumed its own universality, extended rights selectively, prioritized individual and political rights over distributive and economic justice, and often served to mask extant power structures. Offering a set of rights closely aligned with the Western liberal democratic order, the Universal Declaration of Human Rights presented itself as the "common standard of achievement for all peoples and all nations." 194 As discussed above, foundational rights contained in the ICCPR were not extended to certain groups such as undocumented migrants or individuals outside the jurisdiction or

187. See id. at 15-16 (discussing ius gentium and dominium).

188. Id. at 35 .

189. Id. at 32 .

190. See Stammers, supra note 45, at 73-74 ("[T] he philosophical justification of natural rights was a complete fiction which bore no relation to history or social reality.").

191. Id. at 75 .

192. EvANS, supra note 32 , at $15-16$.

193. Id. at 16.

194. UDHR, supra note 11, at pmbl.; MUTUA, supra note 25, at 18, 46. 
territory of the state. ${ }^{195}$ While the ICCPR and the ICESCR were enacted at the same time, the former created binding obligations on states, with compliance mandatory in the short term, while much of the latter was characterized as aspirational, with compliance a goal for the long term. ${ }^{196}$ The primacy of civil and political rights, and in particular negative rights associated with liberty, security, and property, "offer a moral and normative foundation" for justifying the global economic order. ${ }^{197}$

The twin phenomena of universal and individual rights have a complicated historical record. These ideas radically revolutionized the relationship between individuals and the state. Yet they also entrenched a particular approach to social change-an approach susceptible to co-optation by powerful interests anathema to the emancipatory goals of rights regimes. ${ }^{198}$ This subpart explored the historical origins of the flaws of universal individualism. As described in greater detail above, the assumption of universality is rarely borne out in practice; cultural differences exist and cannot easily be papered over. The scope of universal rights is often overstated; in the very instruments claiming universal applicability, individuals and groups are accorded differing levels of protection. The prioritization of individual and political rights fails to address systematically structural and economic harms. Perhaps of greatest concern, the transcendent language of universal individualism disguises its limitations and perpetuation of extant power structures. The next subpart examines further the economic imbalances created by globalization, focusing in particular on the ways in which universal

195. See Linda Bosniak, Human Rights, State Sovereignty and the Protection of Undocumented Migrants Under the International Migrant Workers Convention, 25 INT'L MigRATION REV. 737, 737 (1991) (concluding that "the [ICCPR]'s ability to substantially ameliorate the human rights situation of irregular migrants is significantly constrained by its over-riding commitment to the norms and structures of sovereign statehood").

196. ICCPR, supra note 16; International Covenant on Economic, Social and Cultural Rights, G.A. Res. 2200 (XXI), U.N. Doc. A/6316 (Dec. 16, 1966).

197. Evans, supra note 32, at 43-44; see Alex Kirkup \& Tony Evans, The Myth of Western Opposition to Economic, Social, and Cultural Rights?: A Reply to Whelan and Donnelly, 31 HuM. RTS. Q. 221, 226-32 (2009) (discussing the private-sector-fueled backlash to the idea of including social and economic rights in any list of universal rights).

198. See, e.g., Baxi, supra note 13, at 163-64 ("This new [trade-related, market friendly, human rights] paradigm reverses the notion that universal human rights are designed for the dignity and well being of human beings and insists, instead, upon the promotion and protection of the collective rights of global capital in ways that 'justify' corporate well-being and dignity over that of human persons."); RAJAGOPAL, supra note 22 , at 246 (describing the "uncritical acceptance of the counter-sovereignty liberal rights rhetoric, without examining the socioeconomic and cultural foundations of rights and sovereignty" as one of two weaknesses that "have greatly reduced the transformatory potential of international human-rights discourse, and instead made it into a handmaiden of particular constellations and exercises of power"). 
individualism entrenches the vulnerability of undocumented migrants.

\section{B. Globalization and Human Rights: Manufacturing the Undocumented Migrant}

The universal individualist approach to human rights focuses on individuals rather than political and economic systems, offering rights instead of structural solutions. This orientation presupposes autonomous and freely functioning individuals existing on a level playing field. Yet the global economic system is marked by dramatic inequality. Human rights law's emphasis on the individual diverts attention away from distributive inequities, thereby increasing the vulnerability of economically marginalized populations. This prioritization of the individual also masks the political choices that underlie both the current human rights system and the current economic structure. It narrows the debate to focus on particular individual rights rather than critically examining larger power structures and their beneficiaries. The case study of undocumented migrants illustrates the ways in which universal individualism furthers global economic inequity and begins to suggest alternate approaches to protecting vulnerable populations.

Migration, particularly economic migration, is typically conceived of as a choice made by an autonomous individual actor. This is a misconception. ${ }^{199}$ Undocumented migrants are often trapped in systems of economic disadvantage that are almost impossible to transcend, with few options but to migrate in order to provide basic sustenance for themselves and their families. ${ }^{200}$ But the global structural economic conditions producing the migrant and their status as undocumented are rarely discussed; both in human rights law and in the public sphere, the focus in determining the validity of rights claims is on whether the migrant is lawfully present. ${ }^{201}$

Globalization, or the "closer integration of the countries and peoples of the world," can be attributed to decreasing costs of communication and transportation and the dismantling of obstacles to cross-border flows of capital, goods, information, and services. ${ }^{202}$

199. Dora Kostakopoulou, Irregular Migration and Migration Theory: Making State Authorisation Less Relevant, in IRREGUlaR MigRATION AND HUMAN RIGHTS: Theoretical, European And International Perspectives 41, 42 (Barbara Bogusz et al. eds., 2004) ("[I]rregular migration is often seen as an external and objective challenge facing the state, rather than a law-enforcement and labour market event.”).

200. Fineman, supra note 33, at 257.

201. See Khalid Koser, The Case for Global Governance of International Migration, FoRUM, Fall 2010, at 31-32 (discussing the multiplicity of powerful "forces that drive international migration," and arguing that "international migration has become an archetypal example of a global issue that is still largely governed at a national level").

202. Joseph E. Stiglitz, Globalization And Its Discontents 9 (2002). 
Though its precise commencement date is difficult to pinpoint, the pace of economic globalization increased with the advent of neoliberal economic policies in the $1980 \mathrm{~s}$. While cross-border movement has become cheaper and faster in the globalized economy, most of the world's population does not benefit from the same principles of free movement accorded to capital, goods, information, and services. ${ }^{203}$

Globalization has benefited the world economy in numerous ways, driving economic growth through exports and raising standards of living throughout the world. ${ }^{204}$ Yet it has also contributed to growing inequality between rich and poor countries. ${ }^{205}$ The United Nations Development Programme reports that in 1975, the per capita gross domestic product in high-income countries was forty-one times that of low-income countries; by 2004, it was sixty-six times greater. ${ }^{206}$

The reasons for this increase in inequality are numerous and multifaceted. It may in part be attributed to the "brain drain," or loss of skilled workers such as teachers, doctors, and nurses to the developed world, which negatively impacts education and health in developing nations. ${ }^{207}$ It may be due in part to misguided or inadequate economic development policies pursued by poorly functioning governments in developing nations. International financial institutions, particularly the International Monetary Fund and the World Bank, have also played a role by pursuing economic policies that protected the interests of investors in the developed world at the expense of the growth and stability of developing economies. ${ }^{208}$ These institutions forced developing countries to pursue neoliberal approaches to development-strategies focused on preventing inflation rather than unemployment, benefiting Wall Street investors but harming developing nations and their residents. ${ }^{209}$ Similarly, trade agreements between developed and developing nations have opened the markets of the latter to subsidized exports from the former, leading to import dependence and extreme sensitivity to currency fluctuations in much of the developing world. ${ }^{210}$

203. Global COMm'N ON InT'L Migration, Migration in an Interconnected WORLD: NEW DIRECTIONS FOR ACTION 15 (2005).

204. STIGLITZ, supra note 202, at 4.

205. See, e.g., Irregular Migrants in Europe, supra note 69, at 5.

206. GLOBAL COMM'N ON INT'L MigRATION, supra note 203, at 12.

207. See, e.g., Irregular Migrants in Europe, supra note 69, at 5.

208. STIGLITZ, supra note 202, at 15.

209. Id. at 6, 8, 12, 54-57, 60-62, 171-72.

210. See, e.g., id. at 208-11, 238, 244 (explaining that small developing countries face great risks from currency fluctuations and that "[w]hile [the advanced industrial] countries had preached-and forced-the opening of the markets in the developing countries to their industrial products, they had continued to keep their markets closed to the products of the developing countries, such as textiles and agriculture. While they preached that developing countries should not subsidize their industries, they 
The factors that push individuals to migrate are complex and difficult to isolate. With that caveat in mind, the economic consequences of global political and economic power imbalances have, in many cases, played a role in increasing unemployment in and migration from the developing world. In West Africa, for example, the post-1997 decline in world cotton prices caused by subsidized cotton exports from the United States and the European Union led to the collapse of local cotton markets. This loss of income for farmers in areas where cotton is the only crop led to increased poverty levels, diminished state health and education budgets, and, eventually, migration to Europe. ${ }^{211}$ In Mexico, the North American Free Trade Agreement led to a flood of subsidized U.S. corn imports. ${ }^{212}$ The Mexican government provided subsidies to larger farms, but small farms throughout Mexico were unable to compete with the low-priced corn from the United States. An estimated two million Mexicans lost their farms or farm jobs and were unable to transition to factory work. Many had no choice but to migrate to the United States to find gainful employment. ${ }^{213}$

The benefits of this migration to economies in both the developed and the developing world are substantial. Migrants in the developed world remitted an estimated $\$ 414$ billion to their home countries in 2013-more than three times the size of official development assistance. $^{214}$ For employers in migrant-receiving states, the vulnerability of undocumented migrants renders their labor cheap, flexible, and convenient. ${ }^{215}$ The industrial world has an ongoing need for such labor, as many lawful residents of wealthier nations refuse to take on the work performed and wages received by undocumented

continued to provide billions in subsidies to their own farmers, making it impossible for the developing countries to compete.").

211. See, e.g., Irregular Migrants in Europe, supra note 69, at 5.

212. Elizabeth Becker, U.S. Corn Subsidies Said to Damage Mexico, N.Y. TIMES (Aug. 27, 2003), http://www.nytimes.com/2003/08/27/business/us-corn-subsidies-said-todamage-mexico.html [http://perma.cc/Z3XD-9W2A] (archived Feb. 17, 2014); Timothy Wise, The Impacts of U.S. Agricultural Policies on Mexican Producers, in SUBSIDIZING INEQUALITY: MEXICAN CORN POLICY SinCE NAFTA 163, 165 (Jonathan Fox \& Libby Haight eds., 2010), available at http://www.ase.tufts.edu/gdae/Pubs/rp/ AgricDumping.pdf [http://perma.cc/RW2Q-K64N] (archived Feb. 17, 2014).

213. Tim Johnson, Free Trade: As U.S. Corn Flows South, Mexicans Stop Farming, MCCLATCHY DC (Feb. 1, 2011), http://www.mcclatchydc.com/2011/02/01/ 107871/free-trade-us-corn-flows-south.html [http://perma.cc/59QF-84NX] (archived Feb. 17, 2014).

214. World Bank, Migration and Remittances: Background, THE WORLD BANK: NEWS \& BROADCAST, http://web.worldbank.org/WBSITE/EXTERNAL/NEWS/0, contentMDK:20648762 pagePK:64257043 piPK:437376 theSitePK:4607,00.html (last updated Sept. 2013), [http://perma.cc/M5HC-YCB2] (archived Feb. 17, 2014).

215. See, e.g., Bustamante, supra note 67, at 344 (arguing that the vulnerability of immigrants is associated with the low cost of their labor). 
migrants. ${ }^{216}$ This need will only increase as fertility rates decline in developed nations. ${ }^{217}$

For many undocumented migrants, the global economic structure drives the decision to migrate. As unemployment increases in the developing world and developed economies offer jobs that their nationals will not accept, as travel becomes cheaper and links between transnational diaspora become easier, the pressure to migrate grows. ${ }^{218}$ Yet globalization has not resulted in increased free cross-border movement of people. To the contrary, there is a dearth of legal migration channels for low-skilled labor. ${ }^{219}$ Nationals of the developing world without connections, education, or wealth have little other option than to become undocumented migrants. These are not the autonomous individuals that universal individualism imagines; their ability to enter developed countries lawfully and thus obtain many of the benefits of human rights law is severely limited.

Human rights law's narrow focus on individual rights prevents inquiry into the root causes of migration as well as the benefits that developed nations receive from both the labor of undocumented migrants and the economic policies that push undocumented migrants to leave home. This myopia stifles not only legal decisions concerning the rights of undocumented migrants but also broader debate about the situation of the undocumented. Universal individualism pushes out of view questions about distributive inequality and the political choices that determine current economic structures. Instead of protecting the vulnerable from the harmful effects of globalization, universal individualism enables global inequity.

\section{ReAlizing a New ApPROACH to PRotecting Undocumented MigRANTS}

In the world of social justice, universal individualism in the form of international human rights law has become the hegemon. Efforts to protect vulnerable populations begin and end with human rights. Particularly in legal scholarship, strategies to ameliorate the

216. Global COMM'N ON INT'L Migration, supra note 203, at 16 (contending that "cheap and flexible labor" done by immigrants is often "shunned by nationals").

217. See id. at 13 (explaining that fertility levels in developed nations are "below the replacement rate").

218. See, e.g., Irregular Migrants in Europe, supra note 69, at 5 (asserting that economic globalization is a "principal 'driver[ ]' of contemporary international migration").

219. European Comm'n, Pathways into Irregularity: The Social Construction of Irregular Migration, Clandestino Research Project Overview 2 (Oct. 2009), available at http://irregular-migration.net/typo3_upload/groups/31/4.Background_Information/4.2. Policy_Briefs_EN/ComparativePolicyBrief_PathwaysIntoIrregularity_Clandestino_Nov 09_2.pdf [http://perma.cc/BG4A-E3AJ] (archived Feb. 17, 2014). 
situation of vulnerable groups outside the scope of human rights law focus on how that law might be extended to cover these groups. Given the failures of universal individualism, this Article suggests other approaches outside of or alongside international human rights law that might more effectively protect undocumented migrants and other vulnerable populations.

This Part first examines the ways in which the existing human rights structure might be altered to address the problems described in the prior Part. It then suggests a state-based political approach as an alternative emancipatory strategy, focusing in particular on the possibilities of a coalition of migrant-sending states. Finally, this Part raises the prospect of mechanisms to aggregate voices globally outside the state, drawing from the literature on social movements. Of course there is overlap, direct and indirect, across these categories: social movements might impact the ways human rights bodies understand and decide cases, states select representatives to draft and interpret human rights treaties, and individuals move back and forth between these groups, bringing ideas and conceptual frameworks with them. ${ }^{220}$ These broad categories are still helpful in assessing each option as a site of social change. While each of these proposals has limitations, simply exploring them begins to address the impoverishment of our collective imaginations by reminding us of the existence of viable alternatives to universal individualism.

\section{A. Ameliorating the Existing Human Rights Structure: More Universal, Less Individualist}

These critiques of universal individualism might help us to imagine a human rights framework that is more effective at protecting undocumented migrants and other vulnerable populations. A process of radical contestation might be able to reshape international human rights law to make it more universal in coverage and content and less individualist in focus. Even if this contestation fails to amend the law itself, it might play a role in shifting the public debate.

Contestation over the scope of human rights law is, of course, already occurring in regional human rights bodies and other fora. With respect to undocumented migrants, this contestation must become more radical if it is to address the failures of universal individualism. Regional interpretive bodies such as the InterAmerican human rights system have already extended certain rights to undocumented migrants. These bodies could go further by, for

220. See Elena Baylis, Tribunal-Hopping with the Post-Conflict Justice Junkies, 10 OR. REV. INT'L L. 361 (2008) (discussing how internationals who work on postconflict justice issues transport conceptual frameworks between different post-conflict settings and institutions). 
example, interpreting the American Convention on Human Rights to give rise to a right to territorial security beyond the right to family unity. Though not yet approved by the UN General Assembly, the International Law Commission's Draft Articles on the Expulsion of Aliens could offer persuasive authority in human rights fora for the right to due process in immigration proceedings and perhaps even a broader right to territorial security. ${ }^{221}$

In doing so, these human rights treaty bodies should highlight the political choices that are made in determining the content of human rights law, discuss the broader distributive inequality that gives rise to irregular migration, and emphasize the importance of social connections for migrants and for migrant-receiving societies. This may also be a role for treaty executives and special rapporteurs, whose reporting could discuss in greater detail the ways in which the developed world benefits economically and socially from migration flows. Such reports might be cited directly by treaty bodies or might be introduced by nongovernmental organizations (NGOs) or others in "friend of the court" briefs.

An even more radical approach would be for a UN treaty body or an international organization to issue documentation to undocumented migrants. This is a new spin on an old idea. In 1942, the League of Nations began to issue Nansen passports, internationally recognized identity cards that enabled stateless refugees to travel. ${ }^{222}$ Undocumented migrants are not in need of passports but could benefit from internationally recognized documentation that enables them to drive and open bank accounts and even suggests that they should not be deported without due process and the opportunity to establish their right to territorial security.

This approach has obvious limitations. It is extremely difficult to expand the content of human rights law without amending existing treaties or drafting new treaties. ${ }^{223}$ The fate of the Migrant Workers Convention, which simply repackages existing rights, demonstrates the near impossibility of convincing migrant-receiving states to alter the content of hard treaty law in ways that would better protect lawful migrants, let alone the undocumented. ${ }^{224}$ In the absence of a

221. See Expulsion of Aliens, supra note 112, at Draft Arts. 3-5 (requiring that expulsion take place only in accordance with law, the draft articles, and other rules of international law, including international human rights law).

222. Nansen - A Man of Action and Vision, United NATions High COMm'R FOR REFUGEES (Sept. 14, 2009), http://www.unhcr.org/4aae50086.html.

223. Cf. T. Alexander Aleinikoff, International Legal Norms on Migration: Substance Without Architecture, in INTERNATIONAL MigRATION LAW: DEVELOPING PARAdigms AND Key Challenges 467, 477-79 (Ryszard Cholewinski, Richard Perruchoud \& Euan MacDonald eds., 2007) (suggesting an international bill of rights for migrants)

224. For a discussion of the Migrant Workers' Convention, see supra note 74 and accompanying text. 
new treaty, and in the face of existing interpretations of treaty law, even treaty bodies relatively sympathetic to undocumented migrants such as the Inter-American Human Rights Commission and its court face challenges in extending the coverage and content of human rights law. Human rights bodies such as the UN Human Rights Committee and the European Court of Human Rights are even less likely to radically reimagine human rights law in ways that might lead Member States to question the legitimacy of these institutions. Even the sympathies of the Inter-American human rights bodies, composed as they are of representatives of states that may be both migrant sending and migrant receiving, may have limits when it comes to undocumented migrants. ${ }^{225}$ The idea of expanding the considerations that influence a treaty interpretive body's decision to include global economic inequality and social connections, not to mention criticism of the politicized nature of human rights, is not entirely realistic in a legal forum. Legal decision making is inherently limited to facts and legal standards deemed pertinent to the case in point, excluding broader contextual questions. ${ }^{226}$ Because there is no international organization or treaty body that focuses on or protects robustly the rights of undocumented migrants, and because the United Nations is composed of states, the most powerful of which are migrant-receiving states, these bodies seem an unlikely source of radical changes to human rights law.

\section{B. Long Live Sovereignty?: A State-Based Approach}

It may be more effective to answer this fundamentally political problem with a political response. One such avenue would involve the governments of migrant-sending states, which could contest current depictions of undocumented migrants in the public sphere and demand better treatment of their nationals in receiving states. In contrast to the individualist approach of human rights law, migrantsending states could aggregate the voices of their citizens abroad, rendering these perspectives more powerful on the world stage. Through various means, migrant-sending states could redirect the discussion to focus on the harms facing the undocumented, contextualized to address the root causes of migration flows and benefits of global inequity for receiving states as well as the social ties that migrants have with citizens of host countries. Migrant-sending states could take a bilateral or multilateral approach to political dialogue with migrant-receiving states.

This political approach is more viable than the proposal to rework the existing human rights structure because it is freed from

225. See infra for a discussion of states that are both migrant-sending and migrant-receiving.

226. See, e.g., Ramji-Nogales, supra note 20, at 10-11. 
the constraints of the legal framework. As noted, discussions in the political sphere can encompass global economic disparities and social ties, contextualizing the situation of undocumented migrants. It would be much more effective to engage in political discussions that aim to change the terms of the debate-to focus, for example, on the ways in which global inequality provokes migration rather than particular provisions of the ICCPR. A political approach can also recognize that there is no global consensus on how to approach international migration law. ${ }^{227}$ Migrant-receiving states tend to favor a control approach while migrant-sending states are more likely to favor a protection approach. ${ }^{228}$ This may be why past efforts to find universal agreement in this realm have failed, in the process obscuring the perspectives of the politically weaker migrant-sending states.

A bilateral process might involve migrant-sending states requesting political reciprocity from states that receive their nationals as migrants, or it might take the form of consular protection. The more powerful migrant-sending states already engage in some forms of each type of political dialogue, though the former could be sharpened and the latter could be expanded upon in these and other states. Political reciprocity demands from public officials in migrant-sending states should be accompanied by media strategies that can help to shift public opinion in the migrant-receiving states. Consular protection strategies can include migrant-sending states providing services to their nationals in migrant-receiving states as well as lawsuits by migrant-sending states against migrant-receiving states.

A political reciprocity approach should be grounded in arguments about the benefits that receiving states gain from their migrant populations and the consequences of global inequality for migrants and migrant-receiving states. More powerful migrant-sending states do currently express in the political sphere concerns about the treatment of migrants, but these statements do not generally draw on reciprocity arguments. ${ }^{229}$ Such official government statements might

227. Aleinikoff, supra note 223 , at $475-76$.

228. This is of course a simplification of reality, not least because many states fall into both categories. See infra for a discussion of states that are both migrantsending and migrant-receiving.

229. See, e.g., Randal C. Archibold, Mexico: Official Assails Migration Bill, Saying Fences 'Are Not the Solution', N.Y. Times (June 25, 2013), http://www.nytimes.com/2013/06/26/world/americas/mexico-official-assails-migration-billsaying-fences-are-not-the-solution.html?_r=1\& [http://perma.cc/ABV3-EEN8] (archived Mar. 2, 2014) (quoting Mexican Foreign Minister Jose Antonio Meade as saying "Fences do not unite us .... They are not the solution to the migratory phenomenon and are not consistent with a secure and modern border. They do not contribute to the development of a competitive region." The article notes that Mexico has kept quiet during the debate over comprehensive immigration reform in the United States due to fears of a backlash). 
be framed with rhetoric and statistics on the economic benefits migrant-receiving states gain from migrant labor. Instead of depicting the issue as one of beneficence or regional cooperation, migrant-sending states could set up the treatment of undocumented migrants as a quid pro quo-we are giving you benefits in the form of labor, so you are obligated to treat our citizens humanely. The migrant-sending states could also highlight, again relying on authoritative research, the global economic forces that push migrants to seek employment abroad and the ways in which these forces benefit migrant-receiving states.

To be most effective in impacting public opinion in migrantreceiving states and minimizing political backlash, these statements by officials of migrant-sending states should be preceded and accompanied by a comprehensive media strategy. Such a strategy could take a range of forms, from social media and YouTube clips to popular television shows and advertisements to mass-marketed movies and documentary films. Through these fora, migrant-sending states could raise awareness of the economic benefits of migrant labor and global inequality for migrant-receiving states. Such a media strategy should also highlight the harm suffered by undocumented migrants during their journeys and in their host states, emphasizing the impact on their communities and families. As an increasing percentage of the populations of migrant-receiving states come from recent immigrant stock, these media strategies might have more traction among voters. ${ }^{230}$

On the consular protection front, many migrant-sending countries have expanded beyond the traditional consular role of issuing passports and visas and certifying legal documents to include various types of assistance for nationals abroad. The Salvadoran Embassy in the United States, for example, offers immigration legal services. ${ }^{231}$ The Mexican and Pakistani Consulates in the United States offer national identification cards for their citizens that can be used, for example, to open bank accounts. ${ }^{232}$ In the United Arab Emirates, the Indian Embassy provides a hotline for domestic

230. United Nations, Department of Economic and Social Affairs, Population Division, Trends in International Migrant Stock: The 2008 Revision (U.N. Database, POP/DB/MIG/Stock/Rev.2008), available at http://esa.un.org/migration/index.asp? panel=1 [http://perma.cc/DW2T-7E8W] (archived Feb. 17, 2014) (select "International migrants as percentage of population" hyperlink in first dialog box; then select "More developed regions" hyperlink in the second dialog box; then hit "Display" button) (stock of international migrants in more developed regions has increased from 7.2 percent in 1990 to 10.3 percent in 2010).

231. Dovelyn Rannveig Agunias, Institutionalizing Diaspora Engagement Within Migrant-Origin Governments, in Closing THE Distance: How Governments Strengthen Ties With Their Diasporas 1, 13 (Dovelyn Rannveig Agunias ed., 2009).

232. Id. 
workers, and the Consulate of the Philippines provides a safe house for migrants escaping abusive employers. ${ }^{233}$

Some relatively powerful migrant-sending states, such as Mexico and the Philippines, have created innovative governmental structures to assist their nationals, including undocumented migrants, abroad. Mexican consulates in the United States provide their nationals with numerous services, including identity documents. ${ }^{234}$ The Institute for Mexicans Abroad, part of Mexico's Ministry of Foreign Affairs, ${ }^{235}$ reaches Mexican citizens in the United States by way of the consulates. ${ }^{236}$ The Institute offers services for Mexican citizens in the United States, including education, health, business promotion, consular protection, and community organization. ${ }^{237}$ It also promotes understanding of the Mexican culture and facilitates immigrant integration in the United States. ${ }^{238}$

The government of the Philippines has three different government offices charged with protecting its workers abroad. The Philippine Overseas Employment Administration (POEA), part of the Department of Labor and Employment, oversees temporary employment in foreign countries, including licensing and accrediting recruitment agencies. ${ }^{239}$ POEA requires that overseas workers be provided with an employment contract providing for minimum terms and conditions of work. It authorizes Filipino workers to be sent abroad only to countries with laws that protect their rights and mechanisms to enforce those rights and holds predeparture seminars to inform workers of those rights. ${ }^{240}$ POEA assistance focuses on migrants who are authorized to work in their receiving state, but the structure it creates helps to ensure that its migrants do not become undocumented. The Overseas Workers Welfare Administration, part

233. Id. at 14

234. See Kevin O'Neil, Consular ID Cards: Mexico and Beyond, MigRATION POL'Y INST. (Apr. 1, 2003), http://www.migrationpolicy.org/article/consular-id-cardsmexico-and-beyond [http://perma.cc/Q5XK-5XNR] (archived Feb. 21, 2014) (describing the matríucla consular, a form of identification that Mexican consulates issue to Mexican citizens living abroad).

235. Laureen laglagaron, Protection Through Integration: The Mexican Government's EFFoRTS to AID MigRANTS In the United STATES 10 (2010).

236. Cristina M. Rodríguez, Building Capacity for the Transnational Regulation of Migration, 110 COLUM. L. REV. SiDEBAR 1, 3 (2010).

237. LAGLAGARON, supra note 235.

238. Rodríguez, supra note 236; see LAGLAGARON, supra note 235 (describing the IME as "service-oriented" and a link between the Mexican emigrant community and the Mexican government).

239. See Patricia A. Sto. Tomas, Protecting Overseas Filipino Workers: The Government's Role in the Contract Labor Migration Cycle, in Closing THE DisTANCE: How Governments Strengthen Ties with Their Diasporas 55, 58-59 (Dovelyn Rannveig Agunias ed., 2009) (describing the work and responsibilities of the Philippine Overseas Employment Administration (POEA)).

240. See id. ("As a predeparture protective mechanism, POEA strictly permits deployment only to destination countries that recognize the rights of Filipino workers and have protective mechanisms in place.”). 
of the Department of Labor and Employment, offers a variety of services to Filipino workers overseas, including insurance and health care services, education, training, legal assistance, housing, cultural orientation, and psychological counseling. ${ }^{241}$ The more recently created Office of the Undersecretary for Migrant Workers' Affairs, part of the Department of Foreign Affairs, provides legal advice and support to migrants abroad. ${ }^{242}$

The governments of migrant-sending states could also take up the situation of their migrants abroad before international legal bodies. The ICCPR, for example, authorizes individual complaints against only those Member States that have agreed to its jurisdiction in such cases. Yet nearly all of the major migrant-receiving states that are parties to the ICCPR have agreed to a provision that allows Member States to bring complaints on behalf of their nationals against other Member States. ${ }^{243}$ Unlike the individual-complaints provision, this state-to-state provision has never been used to bring a case. Migrant-sending states might avail themselves of this opportunity to protect their nationals abroad and to influence the content of international human rights law relating to the protection of undocumented migrants.

Migrant-sending states might also consider bringing a suit against migrant-receiving states before the International Court of Justice (ICJ). In the 2010 Diallo decision, filed by the Republic of Guinea on behalf of one of its nationals who had resided lawfully in the Democratic Republic of Congo, the ICJ determined that the scope of diplomatic protection includes human rights. ${ }^{244}$ Even though human rights attach to individuals, the court found that states could bring human rights claims on behalf of their nationals. Moreover, the ICJ showed its willingness to incorporate international and regional human rights law into its jurisprudence and to step beyond the standards promulgated by human rights treaty interpretive bodies. ${ }^{245}$

241. See id. at 59 ("OWWA programs include the provision of insurance and health-care services, education and training through scholarship grants, social services and family programs... and workers' assistance and on-site services such as legal assistance, counseling, provision of temporary housing, and legal representation in court.").

242. Agunias, supra note 231, at 6 .

243. ICCPR, supra note 16, at art. 41. For a list of States Parties that have agreed to the jurisdiction of the Human Rights Committee to hear cases lodged against them by other States Parties, see Rep. of the Hum. Rts. Comm., 82nd-84th Sess., U.N. Doc. A/60/40 (Vol. I), at 156 (listing 48 of the 155 States Parties including Australia, Belgium, Canada, Denmark, Finland, the Netherlands, Spain, Sweden, the United Kingdom, and the United States, but not including France, and with time-limited declarations by Germany and Switzerland).

244. Case Concerning Ahmadou Sadio Diallo, (Guinea v. Dem. Rep. Congo), 2010 I.C.J. 639, ๆ $65-67,161$ (Nov. 30), available at http://www.icj-cij.org/docket/files/ 103/16244.pdf [http://perma.cc/QW82-P9WR] (archived Feb. 17, 2014).

245. Eirik Bjorge, Case Note, Ahmadou Sadio Diallo, Republic of Guinea $v$. Democratic Republic of the Congo, 105 AM. J. OF INT'L L. 3, at 540 (2011); Mads 
In Diallo, the court held that in the provision governing deportation of lawfully present migrants, the definition of "in accordance with law" required domestic immigration law to be compatible with the requirements of international law. ${ }^{246}$ This was an important move because the UN Human Rights Committee had interpreted this provision to be purely procedural, just as the European Court of Human Rights had read a similar provision of the European Convention on Human Rights. Thus the ICJ not only extended the ICCPR's reach beyond procedural protections into substantive protection but also relied on the more progressive standards adopted by the African Commission on Human and People's Rights and the Inter-American Commission on Human Rights to do so. ${ }^{247}$

While bilateral approaches to protecting undocumented migrants are innovative and promising in many ways, they also have several flaws. Media strategies and consular protection efforts are expensive and unaffordable for all but the wealthiest migrant-sending states. The more radical political reciprocity efforts risk political and economic backlash in migrant-receiving states. Binding bilateral treaties to protect migrants abroad would be the ultimate goal of these efforts, but it is very difficult for even the most powerful migrant-sending states to convince migrant-receiving states to sign onto such agreements. ${ }^{248}$ Consular protection efforts through treaty interpretive bodies and the ICJ require a progressive interpretation of human rights law that might not be forthcoming for reasons discussed in more detail in the prior Part. As with the other bilateral strategies, only citizens of the more powerful migrant-sending states have a chance of being adequately protected under such an approach. Even in these states, the political elites may not be willing to represent the interests of undocumented migrants, who generally have little political or financial clout in their home state.

A coalition of migrant-sending states focused on changing the terms of the debate and empowering undocumented migrants regardless of nationality would have a broader and more sustained impact. These states could engage in joint dialogue with migrantreceiving states and establish shared institutions that protect their

Andenas, International Court of Justice, Case Concerning Ahmadou Sadio Diallo (Republic of Guinea v. Democratic Republic of the Congo) Judgment of 30 November 2010, INT'L \& COMP. L.Q. 810, 811 (2011).

246. Case Concerning Ahmadou Sadio Diallo, 2010 I.C.J., ๆ 65.

247. Id. ๆ 68 .

248. For a fascinating historical example of a bilateral migration treaty between the United States and China and the resultant backlash, see David L. Sloss, Polymorphous Public Law Litigation: The Forgotten History of Nineteenth Century Public Law Litigation 45-53 (Santa Clara Univ. Sch. of Law, Working Paper No. 01-14, Jan. 2014), available at http://papers.ssrn.com/sol3/papers.cfm?abstract_id=2380681 [http://perma.cc/PB7P-4WNE] (archived Feb. 17, 2014) (discussing the Burlingame Treaty and subsequent political and legal responses, including the Chinese Exclusion Act). 
nationals abroad. ${ }^{249}$ Just as Brazil, Russia, India, China, and South Africa have plans to form a development bank that could offer an alternative to the World Bank and International Monetary Fund, this or another group of developing nations could create a permanent institution that works to contextualize the situation of undocumented migrants on a stage of broader global injustice and to advocate for equal treatment and lawful status for these migrants. ${ }^{250}$ This groupbased approach would help to embolden states fearing repercussions from migrant-receiving states. The pooled resources and potential infrastructure would make it possible to protect more migrants, including those from less powerful migrant-sending states.

There are already several international and regional mechanisms that coordinate state approaches to migration. These existing processes focus on the exchange of information and facilitation of network development among government officials from different states, rather than altering the behavior of migrantreceiving states. ${ }^{251}$ On the international level, the UN Global Migration Group convenes regular meetings of sixteen UN agencies to encourage the incorporation of international and regional migration law and to coordinate approaches to international migration. ${ }^{252}$ There are currently thirteen active regional consultative processes (RCPs) on migration. ${ }^{253}$ The RCPs assemble governments, international

249. See BENHABIB, supra note 42, at 113, 179-81 (2004) (describing the idea of "democratic iterations").

250. Lydia Polgreen, Group of Emerging Nations Plans to Form Development Bank, N.Y. TiMES (Mar. 26, 2013), http://www.nytimes.com/2013/03/27/world/africa/ brics-to-form-development-bank.html [http://perma.cc/WW8A-NUJR] (archived Feb. 17, 2014); see Eyal Benvenisti \& George W. Downs, The Empire's New Clothes: Political Economy and the Fragmentation of International Law, 60 STAN. L. REV. 595, 629 (2007) (suggesting that major developing democracies form an anti-fragmentation coalition).

251. Regional Consultative Processes: About RCPs, InT'L ORG. FOR Migration, http://www.iom.int/cms/en/sites/iom/home/what-we-do/regional-processes-1/aboutrcps.html [http://perma.cc/TFB5-4UWY] (archived Feb. 17, 2014).

252. What Is the GMG?, UNITED NATIONS GLOBAL Migration Group, http://www.globalmigrationgroup.org/what-is-the-gmg [http://perma.cc/A9Y6-TCBQ] (archived Feb. 17, 2014). The sixteen member agencies are: the International Labor Organization, the International Organization for Migration, the Office of the High Commissioner for Human Rights, United Nations Regional Commissions on Migration, United Nations Children's Fund, United Nations Conference on Trade and Development, United Nations Department of Economic and Social Affairs, United Nations Development Programme, United Nations Educational, Scientific and Cultural Organization, United Nations Entity for Gender Equality and the Empowerment of Women, United Nations High Commissioner for Refugees, United Nations Institute for Training and Research, United Nations Office on Drugs and Crime, the United Nations Population Fund, the World Bank, and the World Health Organization. Global Migration Group Members, UNITED NATIONS GLOBAL MigRATION GROUP, http://www.globalmigrationgroup.org/gmgmembers [http://perma.cc/8SWG-GC9E] (archived Feb. 17, 2014).

253. Regional Consultative Processes: RCPs by Region, INT'L ORG. FOR MiGRATION, http://www.iom.int/cms/en/sites/iom/home/what-we-do/regional-processes1/rcps-by-region.html [http://perma.cc/C8AR-XCGP] (archived Feb. 17, 2014). The 
organizations, and, in some cases, NGOs for informal exchanges of information and nonbinding dialogue on migration-related issues. ${ }^{\mathbf{2 5 4}}$ Some of these processes are explicitly focused on preventing and discouraging irregular migration flows while others prioritize "respect for the human rights of migrants regardless of their status." 255 But none aim to radically restructure the discussion around undocumented migrants.

A state-based approach aimed at altering political dialogue and improving the situation of undocumented migrants would include only migrant-sending states and possibly representatives of civil society. While regional processes may have some impact, an international coalition of migrant-sending states would garner more respect on the world stage. This multilateral strategy could engage in all of the tactics described above but would likely meet with greater success and less backlash. As a group, these states could demand political reciprocity for their laborers, grounding their arguments in discussions of global inequity and social ties in migrant-receiving states. The coalition could undertake a media campaign that would seek to change the political dialogue for all undocumented migrants. It could also set up protection infrastructure in migrant-receiving states that could be accessed by citizens of all Member States. Finally, Member States could coordinate lawsuits in international fora to protect their citizens against abuses in migrant-receiving states. Though it may have more promise than the possibility of altering the existing human rights mechanisms or taking bilateral approaches, a state coalition approach to protecting undocumented migrants has numerous limitations. Many of the more powerful migrant-sending states, such as Mexico and South Africa, also receive a large number of migrants. This might limit the willingness of these governments to offer protection to migrants who are not their

currently active RCPs are: the $5+5$ dialogue, the Abu Dhabi Dialogue, the Bali Process, the Budapest Process, the Colombo Process, the Intergovernmental Authority on Development-RCP, the Intergovernmental Consultations on Asylum, Refugee and Migration Policies,, the Migration Dialogue for Southern Africa, the Migration Dialogue for West Africa, the Mediterranean Transit Migration Dialogue, the Prague Process, the Puebla Process, and the South American Conference on Migration.

254. Regional Consultative Processes, supra note 251.

255. The Bali Process on People Smuggling, Trafficking in Persons and Related Transnational Crimes falls in the former group. About the Bali Process, THE BALI Process on People Smuggling, Trafficking in Persons \& Related Transnat'L CRIME, http://www.baliprocess.net/ [http://perma.cc/K2R9-XW59] (archived Feb. 17, 2014). As does the Migration Dialogue for Southern Africa. Migration DialOGUE FoR S. AFRICA, http://www.migrationdialogue.org/midsa/ [http://perma.cc/SC6C-5CCF] (archived Feb. 17, 2014). The South American Conference on Migration or Lima Process falls in the later group. The South American Conference on Migration, INTERN'L ORG. FOR MigRATION, http://www.iom.int/cms/en/sites/iom/home/what-we-do/regionalprocesses-1/rcps-by-region/sacm.html [http://perma.cc/FH8-63UZ] (archived Feb. 17, 2014). The Puebla Process does as well. Regional Conference on Migration, http://www.rcmvs.org/ (last visited Mar. 19, 2014). 
citizens. While the group-based approach might lead to less political backlash from migrant-receiving states, even the most powerful migrant-sending states are heavily economically dependent on the migrant-receiving states and may be unwilling to engage in behavior that might antagonize these states, even with the protection of a group. These and other competing interests may lead to coordination problems, including defect and exit. In addition to the concern that elites in these migrant-sending states may not represent the interests of impoverished migrants, the more powerful coalition members may be unwilling to represent the interests of the less powerful states.

\section{Social Movements: Aggregating Interests Beyond the State}

A social movements approach offers greater promise in representing the interests of undocumented migrants. Social movements are forms of popular mobilization that are often local in nature but can extend transnationally through what Peter Evans has termed "counter-hegemonic transnational networks." 256 Three characteristics of social movements are particularly salient in the context of undocumented migrants. First, social movements emphasize a group-based conceptual framework for resolving problems of vulnerability. ${ }^{257}$ Second, social movements focus on the importance of mobilization outside of institutions, legal or otherwise, in order to ensure the success of social change strategies. ${ }^{258}$ Finally, social movements work "[b]y challenging and resignifying what counts as political and who gets to define what's political,"259 enabling the vulnerable to present their own visions of the problems with the current global order and the optimal solutions to those problems. ${ }^{\mathbf{2 6 0}}$

With respect to the flaws of universal individualism, a social networks approach is not beholden to international human rights law's categories, so it need not exclude certain groups in order to better protect others. Social networks could openly address the political choices and economic structures that have manufactured the vulnerability of undocumented migrants. Social networks could also

256. Peter Evans, Fighting Marginalization with Transnational Networks: Counter-Hegemonic Globalization, 29 CONTEMP. SoC. 230, 233, 240 (2000); RAJAGOPAL, supra note 22, at 238; MARGARET E. KeCK \& KATHRYN SiKkinK, ACTIVISTS BEyond BORDERS: ADVOCACY NETWORKS IN INTERNATIONAL POLITICS (1998).

257. Bonaventura de Sousa Santos \& César A. Rodríguez-Garavito, Law, Politics, and the Subaltern in Counter-Hegemonic Globalization, in LAW AND Globalization FROM BELOW: TOWARDS A COSMOPOLITAN LEGAlity 1, 14-16

(Boaventura de Sousa Santos \& César A. Rodríguez-Garavito eds., 2005).

258. Id. at 1, 14-16; RAJAGOPAL, supra note 22 , at 234-35.

259. RAJAGOPAL, supra note 22, at 244.

260. See id. at 248 (explaining that "social movements do not aim to catch-up with the West, but seek to determine what kind of growth is best for them, under what conditions such growth should occur and whether there should be limits to such growth"). 
envision solutions to the situation of undocumented migrants that recognize and respect group identities and social ties.

Social movements are generally characterized by the recognition and integration of social ties in their advocacy approach. This form of mobilization begins with the idea that "[p]olitical struggles are relational; they are not individual," just as identities are enmeshed in social context. ${ }^{261}$ This tenet is, of course, what gives social movements their power. An individual undocumented migrant has little political voice on the world stage, but a broad-based transnational network of migrants might be able to make its perspective heard. A social connection framework has other advantages as well. Rather than creating a discourse that focuses on the rights of individuals, social movements can discuss the social ties that are damaged through deportation of undocumented migrants and underscore the resulting harm to societies of migrant-receiving states. Social movements can also ensure that group-based identities map onto lived experience. For example, the right to family unity under international human rights law focuses on a narrow, Western definition of family as spouse and children. Social movements are not limited by the law and might highlight the harm that results from the rupture of ties to grandparents or aunts and uncles. Social movements can also gain strength by drawing on other group identities, such as national origin or language, to broaden movements for social change.

Social movements step away from primarily legal or institutional approaches to problems, mobilizing instead in the political sphere. Participants in transnational social movements can take advantage of technology to exchange information, build networks, and publicize issues. ${ }^{262}$ Such movements can be nimble, as they are able to determine and avail themselves of the most effective venue and points of leverage for their political strategy; they are not constrained by the human rights legal framework or institutional structure. ${ }^{263}$ Social movements can, for example, present compelling stories of harm to undocumented migrants that might be limited or neutralized in court. In contrast to international human rights law, such an approach can also foreground the broader structural reasons for the situation of undocumented migrants. A social movement for undocumented migrants could try to change public opinion through media strategies highlighted in the discussion of bilateral state-based approaches. It might up the ante by organizing transnational protests

261. Id. at 244 .

262. See KECK \& SIKKINK, supra note 256, at 200 ("Faster, cheaper, and more reliable international information and transportation technologies have speeded... [the] growth [of transnational advocacy networks] and helped to break government monopolies over information.").

263. See id. (explaining that "[a]ctivists may 'shop' the entire global scene for the best venues to present their issues, and seek points of leverage at which to apply pressure”). 
that can turn moral leverage into foreign pressure on American policy elites. $^{264}$ A sustained protest effort might create enough concern about political instability to prod political elites in migrant-receiving states to change their migration laws and policies. ${ }^{265}$

Perhaps most importantly, a social movements approach would frame efforts to protect undocumented migrants in their authentic voice. ${ }^{266}$ Rather than being the subject of imposed legal standards, undocumented migrants should be engaged in describing the harms they suffer because of their vulnerability and envisioning creative solutions to the problems they face. By promoting the voices of these migrants in the political sphere, the debate can be challenged and even appropriated in directions that are impeded by the human rights framework. There has been little, if any, effort to date to comprehensively survey undocumented migrants about the problems they face, the harms they would most like to see ameliorated, and how they propose to do so. Such an exploration of migrants' perspectives might find that, for example, migrants who are parents are deeply concerned about harm to their children from family separation. They might favor focusing the political debate on development assistance in the form of job creation efforts in their home countries, or on circular migration policies that allow them to spend six months each year with their children in their home country, or on minimizing restrictive border control processes. ${ }^{267}$

Though a social movements approach to the situation of undocumented migrants has numerous benefits, it also has several shortcomings. In the contemporary global political order in which states have the sovereign authority to control entry and residence, social movements have inherently less power than states to ameliorate the situation of undocumented migrants. Moreover, though political movements may be more effective than law-based approaches to social change in numerous ways, they have less power to alter the law, which is an important determinant of the vulnerability of undocumented migrants. Social movements are also more difficult to coordinate than state-based options, particularly given the nonhierarchical nature of many such movements. Though advances in communication, including social media and smartphones,

264. See id. at 200 ("Linking local activists with media and activists abroad can then create a characteristic 'boomerang' effect, which curves around local state indifference and repression to put foreign pressure on local policy elites.”).

265. Evans, supra note 256, at 239-40 (arguing that the liberal, political, and economic order is more fragile than it appears and is particularly vulnerable to instability and unpredictability in global markets).

266. See, e.g., Baxi, supra note 13, at 135 (explaining the importance of the "right to a voice" in "radical self-determination" which "open[s] up sites of resistance").

267. This Article does not propose an open-border solution. For a thoughtful exploration of such an approach, see KEVIN JOHNSON, OPENING THE FLOODGATES: WHY AMERICA NEEDS TO RETHINK ITS BORDERS AND IMMIGRATION LAWS (2009). 
have simplified political organizing, not all undocumented migrants are able to access such technologies. States and most human rights organizations also have more financial resources than social movements. This is especially true of groups of undocumented migrants, many of whom struggle to make ends meet and send any money they do have to family in their home country.

Of course, these three strategies for social change-the human rights, state-based, and social movements approaches-are not always neatly separated in practice. At times, these strategies might best work in tandem. As discussed above, individual states might use human rights or other international legal mechanisms to demand greater protections for their nationals abroad. A coalition of states might even take a more radical stance and threaten to withdraw from existing human rights treaties unless migrant-receiving states sign on to binding standards to protect migrant workers. States that are unwilling to take action on behalf of undocumented migrants can be prodded by social movements. For example, the government of the Philippines created the Office of the Undersecretary for Migrant Workers in response to public outcry over the maltreatment, illegal recruitment, and deaths of temporary workers. ${ }^{268}$ Families of migrant workers were successful in their efforts in part because remittances are such a large source of income in the Philippines, as they are in many migrant-sending states. Even states that are more willing to take action might be able to rely on social movements to provide political cover for their actions on the world stage. Jennifer Gordon's transnational labor citizenship proposal offers an example of how states and social movements might work together creatively to protect migrant workers. ${ }^{269}$ She suggests that permission to enter the United States to work might be conditioned on membership in a cross-border worker organization, an approach that would enable free movement while allowing migrants to carry labor benefits and services with them and respecting labor rights in receiving countries. $^{270}$ There are many potential marriages of these strategies that would protect undocumented migrants more effectively than the current universal individualist approach.

The vulnerable position in which the undocumented migrant finds herself is caused by complex and powerful forces well beyond her control. None of the solutions presented above offers a magic bullet; indeed, I expect that readers will find much that is politically infeasible about each of them. The aim of this Article is not to work within existing systems to create social change but to push readers to reimagine what is possible when it comes to protecting undocumented

268. Agunias, supra note 231, at 6 .

269. Jennifer Gordon, Transnational Labor Citizenship, 80 S. CAL. L. REV. 503 (2007).

270. Id. at 504 . 
migrants. Even the imaginations of those who seek to protect undocumented migrants are currently impoverished by the strictures of the international human rights framework that governs most social change efforts. This Article is thus an attempt to liberate the discourse around undocumented migrants from the dominant human rights hegemon.

\section{Beyond Human Rights: Engaging With Systemic InJustice}

This Article is at once a radical provocation, a thought experiment, and a deeply serious effort to "rewrite the globalization script by imagining alternative strategies for resistance." ${ }^{271}$ It is a call to reflect critically upon the universal individualist approach and to foreground the political choices and power relations underlying the human rights framework. Only through such an unsparingly honest examination of dominant legal approaches to social change can we hope to imagine effective methods of protecting the vulnerable.

Human rights are not transcendent. They are situated squarely within specific social and political contexts through which they are constructed and enforced. The very real danger of a universal individualist approach is that human rights can appear to reside beyond the political fray while masking deep inequalities that exist within the societies and polities in which they reside. If we are to be serious about alleviating vulnerability, we must constantly be vigilant of this danger and critical of the political and structural roots of human rights.

The first step toward this goal is to interrogate claims to universalism in order to expose hidden power imbalances. ${ }^{272}$ It is to be expected that social values and norms vary tremendously across the globe and that they will differ and even conflict across cultures. ${ }^{273}$ Rather than claiming universal shared truths, we must seek more effective methods of recognizing and reconciling as many perspectives as possible. We must scrutinize universalist approaches to ensure that they are not simply assertions of those who benefit the most from a particular conception of human rights. ${ }^{274}$ This examination involves foregrounding political choices by making clear the ways in

271. Anne Orford, Contesting Globalization: A Feminist Perspective on the Future of Human Rights, 8 TRANSNAT'L L. \& ConTEMP. PROBS. 171, 195 (1998).

272. See EvANs, supra note 32 , at 32 (critiquing the notion of "a global consensus on the purposes and principles of economic, social and political life, which are understood in terms of a single global history").

273. See Stuart Hampshire, Justice is Conflict 4 (2000) ("Justice and fairness in substantial matters ... will always vary with varying moral outlooks ....").

274. Evans, supra note 32, at 32. 
which power determines which vision of justice prevails. ${ }^{275}$ We should ask not only how vulnerable populations can be protected through a given system but also how that system enables vulnerabilities and exposures. ${ }^{276}$ Such an inquiry can create space for dialogue around the relationship between globalization and vulnerability and enable exploration of the ways in which methods of social change have been appropriated to facilitate economic liberalism. ${ }^{277}$

It is also important to recognize the limits of an individualist approach to addressing vulnerability. Though individualism may be appropriate in some cases, it should not be the default method for protecting vulnerable populations. Group-based protection mechanisms can be a more powerful avenue for social change, enabling the vulnerable to alleviate their situation in their own voice. Individualist approaches obscure the value of social ties and the harm to other members of society and society as a whole that results from harm to vulnerable populations.

This Article is a call to shed human rights fetishism ${ }^{278}$ and to diversify the language of resistance beyond universal individualism. ${ }^{279}$ Rather than focusing social change efforts on expanding the content of and improving the methods of implementing international human rights law, those who seek to protect vulnerable populations must ground their efforts in broader questions of structural injustice. ${ }^{280}$ An approach that begins by emphasizing global inequality can ground international distributive obligations in justice rather than charity. ${ }^{281}$ A more critical perspective on international human rights law's claims to universal individualism opens up space to imagine breathtakingly novel avenues to social change.

275. See generally Samuel Moyn, Of Deserts and Promised Lands: The Dream of Global Justice, THE NATION (Mar. 19, 2012), http://www.thenation.com/article/ 166516/deserts-and-promised-lands-dream-global-justice\# [http://perma.cc/7WHF-X6MJ] (archived Feb. 21 2014)

276. See Fineman, supra note 33, at 255 (suggesting an approach to human rights that focuses on the concept of vulnerability ).

277. See Stammers, supra note 45, at 81-82 (analyzing the relationship between human rights and power).

278. Baxi, supra note 13, at 166.

279. See, e.g., RAJAGOPAL, supra note 22, at 232 ("Given its colonial legacy, statist and anti-tradition bias, economistic method, and deep imbrication with the development discourse, human-rights discourse remains, at best, a partial, fragmentary, and a sometimes-useful tool of mobilization - not by any means a sole language of resistance and emancipation for oppressed social majorities around the world.”).

280. See EvANS, supra note 32, at 38-41 (critiquing the human rights focus on legal norms rather than philosophical and political discourse).

281. See BEITZ, supra note 42 , at 127 (comparing the obligation of charity and the obligations of justice). 